\title{
SAR studies on hydropentalene derivatives - important core units of biologically active tetramic acid macrolactams and ptychanolides
}

\author{
Vanessa Lutz ${ }^{\mathrm{a}}$, Fabian Mannchen ${ }^{\mathrm{a}}$, Michael Krebs ${ }^{\mathrm{a}}$, Natja Park $^{\mathrm{a}}$, Claudia Krüger ${ }^{\mathrm{a}}$, Aruna \\ Raja $^{\mathrm{b}}$, Florenz Sasse ${ }^{\mathrm{b}, *}$, Angelika Baro ${ }^{\mathrm{a}}$, Sabine Laschat ${ }^{\mathrm{a}, *}$ \\ ${ }^{a}$ Institut für Organische Chemie der Universität Stuttgart, Pfaffenwaldring 55, 70569 Stuttgart, Germany \\ ${ }^{b}$ Department of Chemical Biology, Helmholtz Centre for Infection Research, Inhoffenstr. 7, 38124 Braun- \\ schweig, Germany
}

\begin{abstract}
Structurally diverse bicyclo[3.3.0]octanes were prepared and tested for their biological activity. Both the antiproliferative activity and the results of phenotypic characterization varied with the substitution patterns. Two derivatives displayed high inhibitory $\left(\mathrm{IC}_{50} \leq 3 \mu \mathrm{M}\right)$ activity against the L-929 cell line, but differed in their mode of action. A cluster analysis with impedance profiling data showed the two compounds in relationship to microtubule interfering compounds. In $\mathrm{PtK}_{2}$ cells treated with both derivatives a perturbing effect on the microtubular network was observed, whereas the actin cytoskeleton in incubated $\mathrm{PtK}_{2}$ cells was disturbed only by one compound. The effects on tubulin and actin polymerization could be confirmed by in vitro polymerization experiments.
\end{abstract}

Keywords: Biological activity, Click chemistry, Hydropentalene, Structure-activity relationships, Synthesis

* Corresponding authors. Tel.: +49 711685 64565, fax: +49 71168564285 (S.L.); tel.: +49 5316181 3429; fax: +49 53161813499 (F.S.).

E-mail addresses: sabine.laschat@ oc.uni-stuttgart.de (S. Laschat), florenz.sasse@helmholtz-hzi.de (F. Sasse). 


\section{Introduction}

Highly substituted bicyclo[3.3.0]octanes (hydropentalenes) represent the core unit of several biologically active natural product families such as tetramic acid macrolactams containing, for example, cylindramide (1), ${ }^{1,2}$ alteramide A (2), ${ }^{3}$ geodin A (3), ${ }^{4,5}$ and aburatubolactam A (4), ${ }^{6,7}$ or ptychanolides $\mathbf{5}, \mathbf{6}^{8,9}$ (Figure 1).
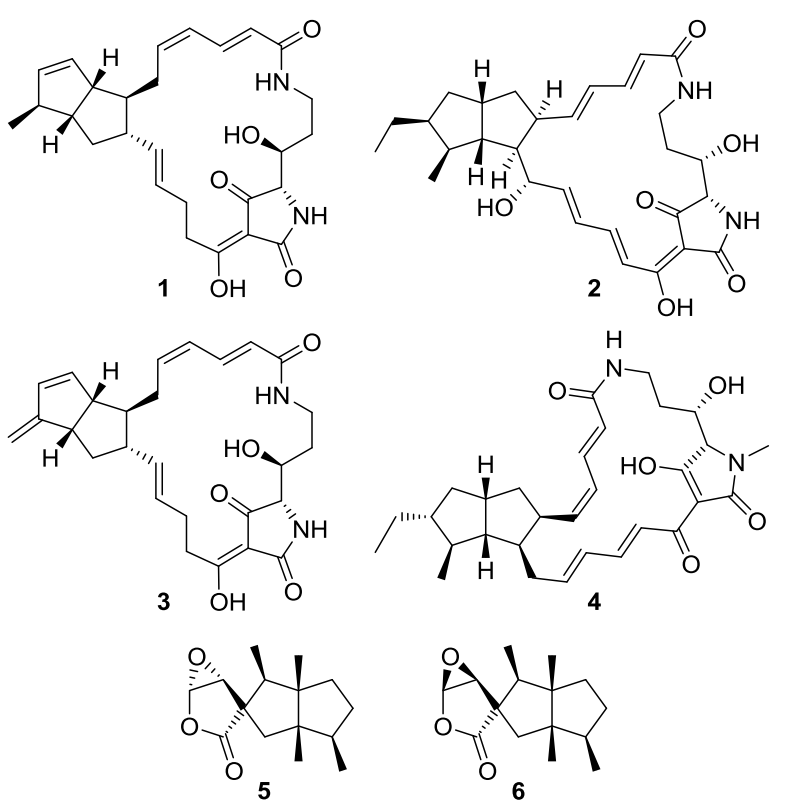

Figure 1. Hydropentalene core containing natural products 1-6.

The class of tetramic acid lactams displays a variety of biological activities. Cylindramide (1), isolated from the marine sponge Halichondria cylindrata in 1989, for example, exhibits pronounced cytotoxicity against B16 melanoma cells. ${ }^{1}$ Alteramide A (2) ${ }^{3}$ from a bacterium Alteromonas sp. associated with the sponge Halichondria okadai is cytotoxic against epidermal carcinoma cell lines. Cylindramide's close relative geodin A (3) being isolated as $\mathrm{Mg}^{2+}$ salt in 1999 from the Southern Australian marine sponge Geodia,${ }^{4}$ differs from $\mathbf{1}$ only in the exocyclic methylene group instead of methyl. Biological studies revealed its strong nematocidal activity against the parasitic nematode Haemonchus contortus. Aburatubolactam A (4) isolated in 1996 from the marine bacterium Streptomyces sp. SCRC A-20 $0^{6}$ inhibits the formation of anionic superoxides which are relevant in both inflammatory and degenerative processes and tumor promotion. ${ }^{10}$ Whereas natural products $\mathbf{1 - 4}$ are of marine origin, a bicyclo[3.3.0] octane skeleton has also been detected in terrestrial sources. For example, the sesquiterpenoids ptychanolide 5 and $\mathbf{6}$ have been isolated in 1981 from the liverwort Ptychanthus striatus (Lehm. et Lindenb.) Nees. ${ }^{8}$ 
Besides some initial experiments on the biological activity of these natural product classes, however, only limited systematic structure-activity relationship (SAR) studies have been carried out. The influence of the tetramic acid moiety on cytotoxicity and antimicrobial properties of macrocyclic acyltetramates has been investigated by Schobert. ${ }^{11}$ Previously we aimed towards elucidation of the mode of action of cylindramide (1). ${ }^{12}$ For this purpose a series of derivatives of $\mathbf{1}$, including analogues where a simple cyclopentane replaced the functionalized hydropentalene moiety, were prepared. A broad biological screening revealed promising antiproliferative activity against several tumor cell lines. The cytotoxicity of $\mathbf{1}$ was found to be calcium dependent and we observed vacuolisation and vesicle formation in the endoplasmic reticulum of $\mathrm{PtK}_{2}$ (potoroo kidney) cells that were incubated with $\mathbf{1}$. A decrease of activity for the cyclopentane analogue of cylindramide (1) indicated that the activity is strongly correlated to the intact functionalized hydropentalene system.

SAR studies of substituted bicyclo[3.3.0] octanes, however, are rarely reported. Most of them focused on orally active PDE4 inhibitors, ${ }^{13}$ carbacycline derivatives such as $\mathrm{TXA}_{2} /$ $\mathrm{PGH}_{2}$ receptor antagonists and prostaglandin analogues, ${ }^{14}$ or mammalian squalene synthase inhibitors. ${ }^{15}$ Therefore, we were motivated to investigate the biological properties of the hydropentalene subunit in more detail. Besides studying analogues of the core units of tetramic acid lactams we were interested in a more general insight into the biological properties of various functionalized bicyclo[3.3.0]octanes A-C. Our results are reported below.

\section{Results and discussion}

\subsection{Chemistry}

In order to supply compounds for SAR studies, a series of bicyclo[3.3.0]octanes was prepared from the easily accessible Weiss diketone (7a), ${ }^{16}$ its dimethyl analogue $7 \mathbf{b}^{16}$ and the known cylindramide core precursor $\mathbf{8}^{2 b}$ (Figure 2) leading to derivatives of structural diversity.

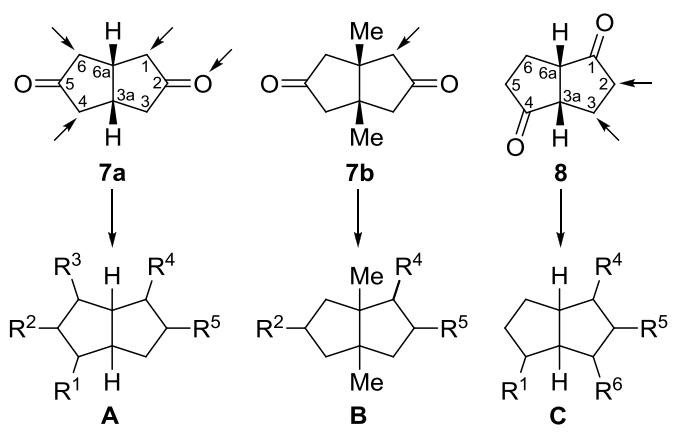

Figure 2. Starting materials and positions for functionalization leading to structures $\mathbf{A}-\mathbf{C}$. 
The hydropentalene derivatives 11-18 are based on Weiss diketone (7a) (Scheme 1). The synthesis of alkynes 11a and 11b which were envisaged for "click chemistry" possibly allowing visualization of the cellular target, commenced with the reduction of monoketal $9 \mathbf{a}^{17,18}$ to give 10. ${ }^{18}$ The latter was either reacted with propiolic acid under Mitsunobu conditions to 11a or converted in three steps to $\mathbf{1 2}$ which was esterified analogously to $\mathbf{1 1 b}$. Direct esterification of alcohol 10 with propionyl chloride gave derivative 11c. Alkenes 17 and 18, providing key structural motifs of the bicyclo[3.3.0]octene core of the natural products $\mathbf{1 - 4}$, were prepared from monoketal 9a by a sequence of double deprotonation/electrophilic trapping followed by swapping of protecting groups to yield compounds 13,14 . Derivatives $13 \mathbf{b}, \mathbf{1 4 b}$ were submitted to Shapiro reaction to give $\mathbf{1 5 b}, \mathbf{1 6} \mathbf{b}$, which were subsequently functionalized to $\mathbf{1 7}, \mathbf{1 8} .^{19}$

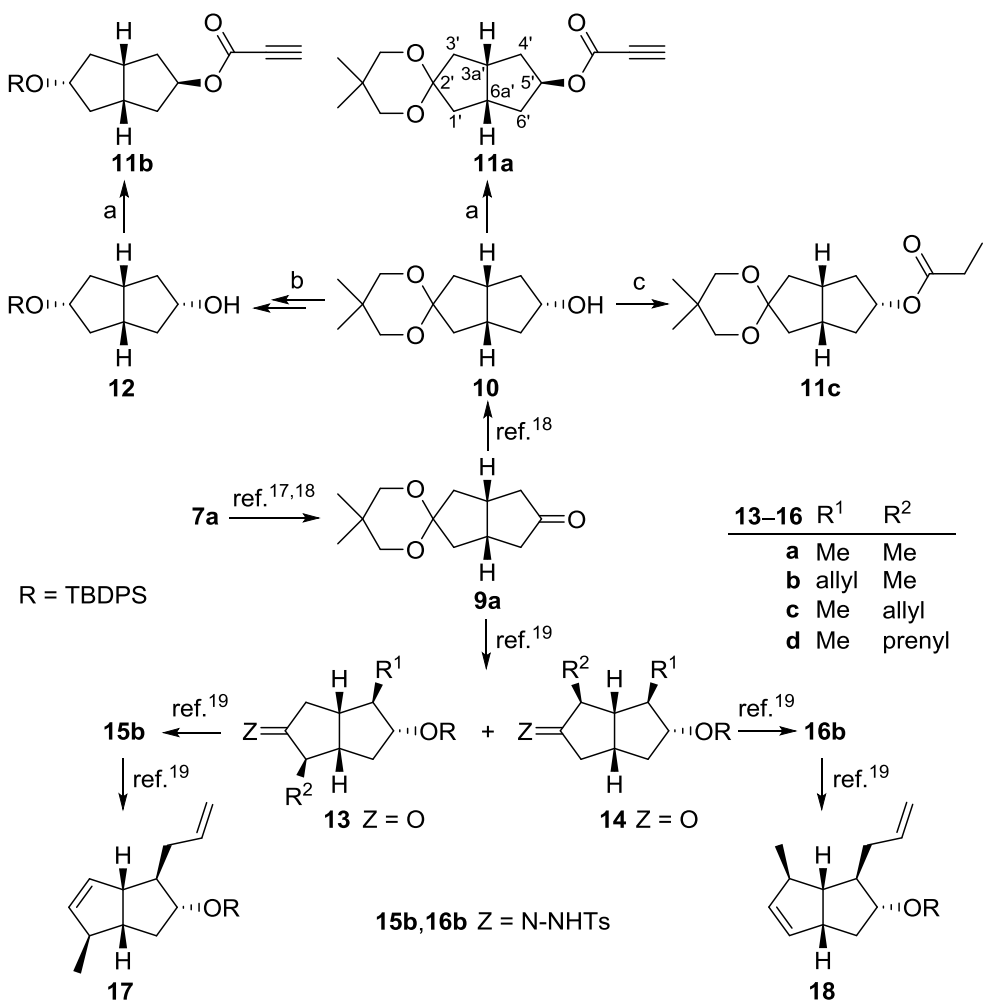

Scheme 1. Reagents and conditions: (a) 4.0 equiv $\mathrm{PPh}_{3}, 4.0$ equiv propiolic acid, 4.0 equiv DEAD, 1.0 equiv 10 or 12, $\mathrm{Et}_{2} \mathrm{O}$, r.t., $24 \mathrm{~h}, 40 \%$ for $\mathbf{1 1 a}, 37 \%$ for $\mathbf{1 1 b}$; (b) 1.0 equiv 5 - $\{[$ tertbutyl(diphenyl)silyl]oxy hexahydropentalen-2(1H)-one, ${ }^{18} 3.0$ equiv $\mathrm{NaBH}_{4}, \mathrm{MeOH}, 0{ }^{\circ} \mathrm{C}, 3$ h, quant.; (c) 1.0 equiv 9a, 2.0 equiv propionyl chloride, $\mathrm{Et}_{3} \mathrm{~N}, \mathrm{CH}_{2} \mathrm{Cl}_{2}, 0{ }^{\circ} \mathrm{C}, 14 \mathrm{~h}, 73 \%$. Numbering for NMR assignment.

The synthesis of hydropentalenes $\mathbf{2 1 - 2 3}$ based on bicyclo[3.3.0] octane-1,4-dione $\mathbf{8}^{2 \mathrm{~b}}$ is shown in Scheme 2. Monoketal 19 was converted to silyl enol ether $\mathbf{2 0}$ which was submitted to a Shi epoxidation. ${ }^{20}$ Reductive epoxide opening of the resulting intermediate with $\mathrm{BH}_{3} \cdot \mathrm{THF}$ provided the trans configured hydropentalenes $21 \mathrm{a}$ and $\mathbf{2 1 b}$. Dienedione $\mathbf{2 2}^{2 \mathrm{~b}}$ yielded the alkylated bicyclo[3.3.0] octene-1,4-dione 23a by Cu-catalyzed Grignard reaction with 3-butenylmagnesium- 
bromide in the presence of TMSCl. Ketalization of 23a with ethylene glycol gave the monoketal 23b (Scheme 2).
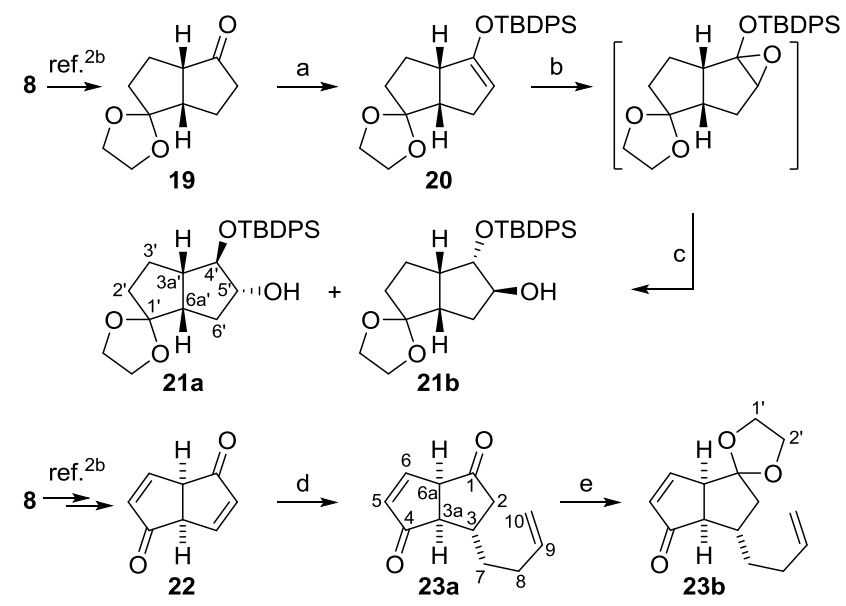

Scheme 2. Reagents and conditions: (a) 1.0 equiv KHMDS, 1.0 equiv 19, THF, $-78^{\circ} \mathrm{C}, 20$ min, 1.1 equiv TBDPSCl, $-78{ }^{\circ} \mathrm{C}$ to r.t., $3 \mathrm{~h}$; (b) aq. $\mathrm{Na}_{2} \mathrm{~B}_{4} \mathrm{O}_{7} \cdot 10 \mathrm{H}_{2} \mathrm{O} / \mathrm{Na}_{2} \mathrm{EDTA} \cdot 2 \mathrm{H}_{2} \mathrm{O}, 0.3$ equiv Shi catalyst, ${ }^{20} 0.04$ equiv $\mathrm{Bu}_{4} \mathrm{NHSO}_{4}, 1.4$ equiv oxone in aq. $\mathrm{Na}_{2} \mathrm{EDTA} \cdot 2 \mathrm{H}_{2} \mathrm{O}, 5.8$ equiv $\mathrm{K}_{2} \mathrm{CO}_{3}, 3 \mathrm{~h}$; (c) 2.5 equiv $\mathrm{BH}_{3} \cdot \mathrm{THF}$, THF, $3 \mathrm{~h}, 15 \%$ for $\mathbf{2 1 a}, 38 \%$ for $\mathbf{2 1 b}$; (d) 1.4 equiv $\mathrm{CuCN}, 1.0$ equiv TMEDA, 1.1 equiv 3-butenylmagnesiumbromide, THF, $-78^{\circ} \mathrm{C}, 1.2$ equiv TMSCl, 1.0 equiv 22, $30 \mathrm{~min}, 63 \%$; (e) 2.0 equiv ethylene glycol, 0.09 equiv $p$-TsOH, reflux, $7 \mathrm{~h}, 60 \%$. Only one diastereomer of 23a was detected, its configuration was determined by NOESY (see supplementary data). Numbering for NMR assignment.

Hydropentalenes of the ptychanolide series were prepared from 3a,6a-dimethyltetrahydropentalene-2,5(1H,3H)-dione $(\mathbf{7 b})^{16}$ following known procedures ${ }^{17,18 \mathrm{~b}, 21}$ (Scheme 3).

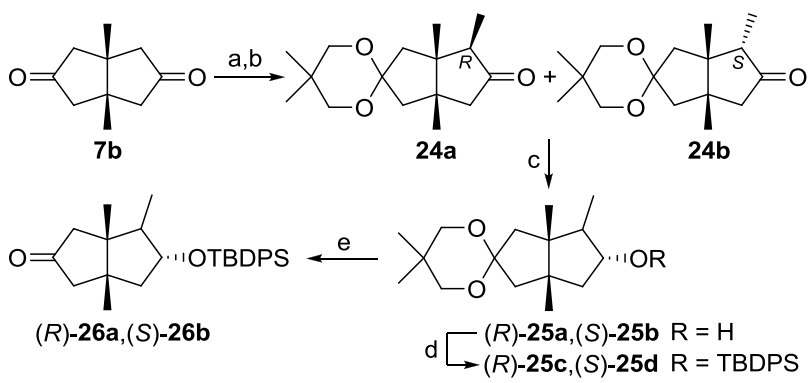

Scheme 3. Reagents and conditions: (a) 2,2-dimethyl-1,3-propanediol, $p$-TsOH in toluene, reflux, $2 \mathrm{~h} ;{ }^{18 \mathrm{~b}}$ (b) $1 . n$-BuLi/bis[ $[R, R)$-1-phenylethyl $]$ ammonium chloride, $-100{ }^{\circ} \mathrm{C}$; then $-78{ }^{\circ} \mathrm{C}, \mathrm{ClSiEt}_{3} ; 2$. MeLi, MeI according to ref.; ${ }^{17}$ (c) 3 equiv $\mathrm{NaBH}_{4}, 1$ equiv $\mathbf{2 4}, \mathrm{MeOH}$, $0{ }^{\circ} \mathrm{C}, 15 \mathrm{~min}$; (d) 1 equiv 25a,b in DMF, 1.2 equiv TBDPSCl, 2.5 equiv imidazole according to ref.; ${ }^{18 \mathrm{~b}}$ (e) catalytic amounts of $p$-TsOH according to ref. ${ }^{21}$

The ratio of the diastereomeric ketones $\mathbf{2 4 a}$ and $\mathbf{2 4 b}$ depended on the temperature. At room temperature, 24a,b were isolated in $87 \%$ yield with $d r 39: 61$ whereas the reaction at $-20{ }^{\circ} \mathrm{C}$ provided 24a,b quantitatively with $d r$ 85:15. The obtained enantioselectivity (10-12\% ee) 
could not be improved by trapping the intermediate enolate as silyl enol ether prior to alkylation as previously reported. ${ }^{17}$ Presumably the steric bias of the axial methyl groups on top of the convex bicyclic roof interfered with the enantiodiscrimination of the chiral lithium amide base at the ketone moiety. Nevertheless, ketones $\mathbf{2 4}$ were reduced to alcohols $\mathbf{2 5 a}, \mathbf{b}$ which were protected to yield silyl ethers $\mathbf{2 5 c}$,d. Final acidic ketal cleavage provided ketones 26a,b.

\subsection{Biological studies - proliferation tests}

The ability of the set of nearly 30 hydropentalene derivatives to inhibit the proliferation of various transformed cell lines including human tumor cell lines was investigated in an MTT assay. ${ }^{22}$ The results are summarized in Tables 1 and 2.

\section{Table 1}

Cytotoxicity of bicyclo[3.3.0]octanes against different transformed cell lines ${ }^{\mathrm{a}}$

\begin{tabular}{llcc}
\hline Entry & Compounds & $\begin{array}{c}\text { L-929 (mouse) } \\
\text { connective tissue } \\
\mathrm{IC}_{50}(\mu \mathrm{M})\end{array}$ & $\begin{array}{c}\text { KB-3-1 (human) } \\
\text { cervix carcinoma } \\
\text { IC }_{50}(\mu \mathrm{M})\end{array}$ \\
\hline 1 & $\mathbf{1 1 a}$ & 2.2 & 21.6 \\
2 & $\mathbf{1 1 b}$ & 9.3 & - \\
3 & $\mathbf{1 1 c}$ & $>142$ & $>142$ \\
4 & $\mathbf{1 3 a}$ & 7.4 & 15.2 \\
5 & $\mathbf{1 3 b}$ & 32.4 & 16.0 \\
6 & $\mathbf{1 3 c}$ & 17.8 & 6.9 \\
7 & $\mathbf{1 3 d}$ & 23.9 & 28.2 \\
8 & $\mathbf{1 4 a}$ & 14.8 & 7.4 \\
9 & $\mathbf{1 4 b}$ & 16.2 & 20.3 \\
10 & $\mathbf{1 4 c}$ & 5.1 & 16.2 \\
11 & $\mathbf{1 4 d}$ & 5.6 & 21.7 \\
12 & $\mathbf{1 5 b}$ & 20.0 & 13.3 \\
13 & $\mathbf{1 6 b}$ & $>67$ & 12.5 \\
14 & $\mathbf{1 7}$ & 20.4 & $>96$ \\
15 & $\mathbf{1 8}$ & 7.2 & $>96$ \\
16 & $\mathbf{2 1 a}$ & 41.0 & - \\
17 & $\mathbf{2 1 b}$ & 38.8 & - \\
18 & $\mathbf{2 2}$ & 3.0 & 6.0 \\
19 & $\mathbf{2 3 a}$ & 20.0 & 16.3 \\
20 & $\mathbf{2 3 b}$ & 25.6 & 32.0 \\
\hline $\mathbf{F}$ & & 2.0 & \\
\hline
\end{tabular}

${ }^{\mathrm{a}}$ Further compounds in supplementary data. $\mathrm{IC}_{50}$ values are means of two assays in parallel. 
As shown in Table 1, the antiproliferative activities of most compounds varied in a micromolar range. Exceptions were the alkyne 11a and dienedione 22 showing promising potencies $\left(\mathrm{IC}_{50} \leq 3 \mu \mathrm{M}\right)$ against L-929 mouse fibroblasts. The cytotoxicity of ester-substituted hydropentalenes 11 was found to depend strongly on the ester function. In contrast to both propiolates 11a and 11b, the corresponding propionate 11c was completely inactive. We were worried that the cytotoxicity of the propiolate derivatives $\mathbf{1 1 a}, \mathbf{b}$ might be due to a subsequent hydrolysis product generated by esterase activity rather than caused by 11a and 11b themselves. Therefore, the corresponding pentalene alcohol was studied in comparison (supplementary data), but no cytotoxicity was observed for the alcohol, indicating that indeed the intact ester seemed to be the active species. Bicyclo[3.3.0]octenes $\mathbf{1 7}$ and $\mathbf{1 8}^{19}$ displayed cytotoxicities $\left(\mathrm{IC}_{50}=7.2-20.4 \mu \mathrm{M}\right)$ against L-929 mouse fibroblasts but poor inhibitory $\left(\mathrm{IC}_{50}\right.$ $>96 \mu \mathrm{M}$ ) activity against the KB-3-1 cell line (Table 1, Entries 14, 15). Unexpectedly, silylprotection had a significant effect on the antiproliferative activity. The unprotected analogues of 13, 14 and 21 were completely inactive against all tested cell lines (supplementary data).

A similar effect was observed for unprotected ptychanolide derivatives $25 \mathbf{a}, \mathbf{b}$ and their silyl-protected counterparts $\mathbf{2 5 c}$,d (Table 2, Entries 2-5). In order to study the influence of the silyl protecting group, the cytotoxic effect of O-silylated cyclopentanols ${ }^{23-25}$ for the two cell lines was investigated. We observed an increased activity in the order of silyl protecting groups TBS < TIPS < TBDPS (Table 2, Entries 8-11).

\section{Table 2}

Cytotoxicity of 3a,6a-dimethylhydropentalenes 24-26 and cyclopentanols against different transformed cell lines ${ }^{\mathrm{a}}$

\begin{tabular}{llcc}
\hline Entry & Compound & $\begin{array}{c}\mathrm{L}-929 \\
\mathrm{IC}_{50}(\mu \mathrm{M})\end{array}$ & $\begin{array}{c}\mathrm{KB}-3-1 \\
\mathrm{IC}_{50}(\mu \mathrm{M})\end{array}$ \\
\hline 1 & $\mathbf{2 4 a}$ & $>150$ & - \\
2 & $\mathbf{2 5 a}$ & $>150$ & - \\
3 & $\mathbf{2 5 b}$ & $>150$ & - \\
4 & $\mathbf{2 5 c}$ & 15.8 & - \\
5 & $\mathbf{2 5 d}$ & 11.8 & - \\
6 & $\mathbf{2 6 a}$ & 14.3 & - \\
7 & $\mathbf{2 6 b}$ & 35.7 & - \\
8 & $t$-butyl(cyclopentyloxy)dimethylsilane & $>200$ & $>200$ \\
9 & (cyclopentyloxy)(triisopropyl)silane & 111.4 & 123.7 \\
10 & $t$-butyl(cyclopentyloxy)diphenylsilane & 61.6 & - \\
\hline
\end{tabular}

${ }^{\mathrm{a}} \mathrm{IC}_{50}$ values are means of two assays in parallel. 


\subsection{Biological studies - target identification}

Alkyne 11a and dihydropentalenedione 22 with the highest potency were selected for further biological studies. In order to get hints about the mode of action we employed a newly developed impedance profiling method which uses time-dependent impedance curves as a fingerprint for the mode of action. ${ }^{26}$ In L-929 cell cultures that were incubated with 11a and 22, impedance was monitored over time (Figure 3).

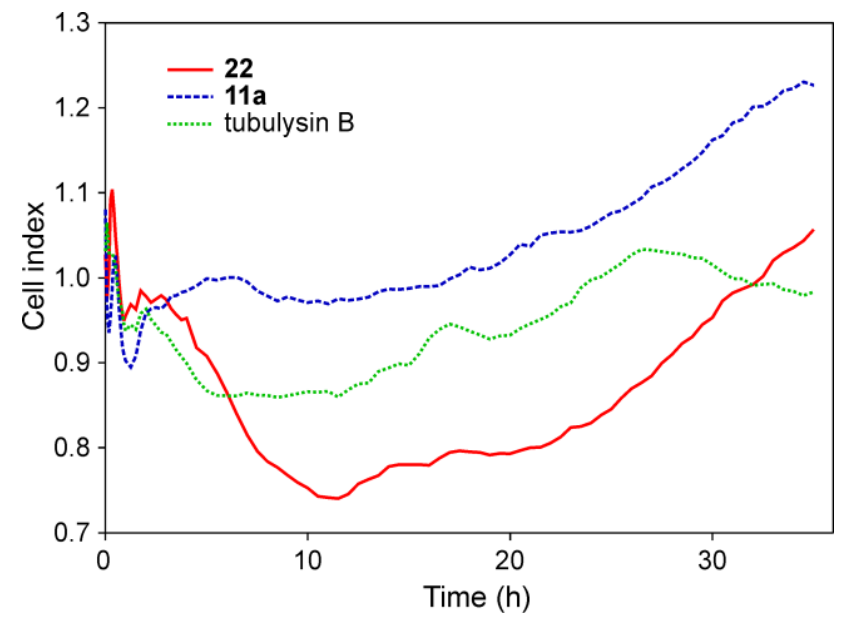

Figure 3. Impedance curves of L-929 cells incubated with $\mathbf{1 1 a}\left(0.6 \mu \mathrm{g} \mathrm{mL} \mathrm{L}^{-1}\right)$ and $22(0.4 \mu \mathrm{g}$ $\left.\mathrm{mL}^{-1}\right)$. Tubulysin $\mathrm{B}\left(3 \mathrm{ng} \mathrm{mL} \mathrm{m}^{-1}\right)$ was used as one of the reference compounds.

The obtained curves were compared with those of a set of reference compounds using statistical methods. Cluster analysis of the resulting data showed 11a and 22 in a group of reference compounds such as nocodazole, tubulysin B and griseofulvin that interfere with microtubule polymerization and spindle formation (Figure 4).

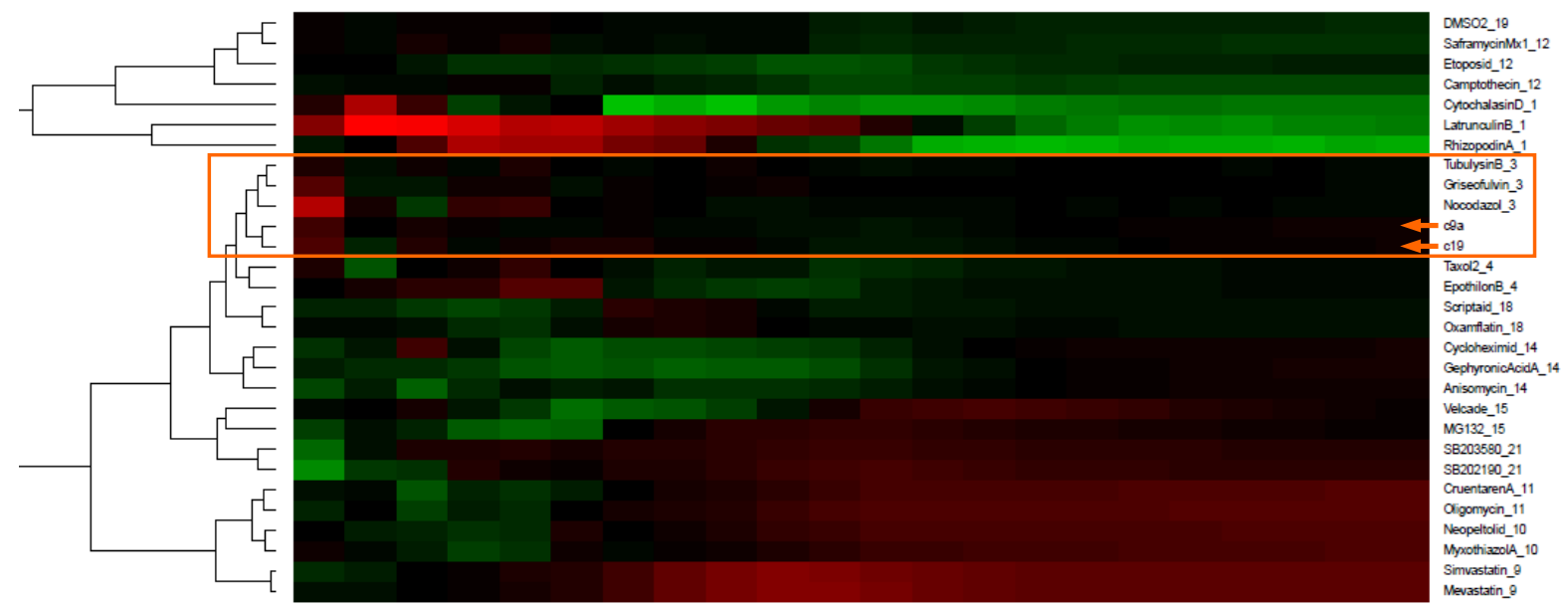

Figure 4. Cluster analysis of data obtained by impedance monitoring of incubated cell cultures. Derivatives 11a (c9a) and 22 (c19) are related to compounds that interfere with tubulin polymerization and mitotic spindle formation. 
Based on the results obtained from the impedance profiling, $\mathrm{PtK}_{2}$ (potoroo kidney) cells which showed in MTT assays an $\mathrm{IC}_{50}$ of approximately $3 \mu \mathrm{M}$ with 11a and 22, respectively, were incubated with both compounds and stained for effects on microtubules (Figure 5). For both 11a and 22 a perturbing effect on the microtubular network in the cells and altered mitotic spindles together with an unusual distribution of chromosomes was visible.
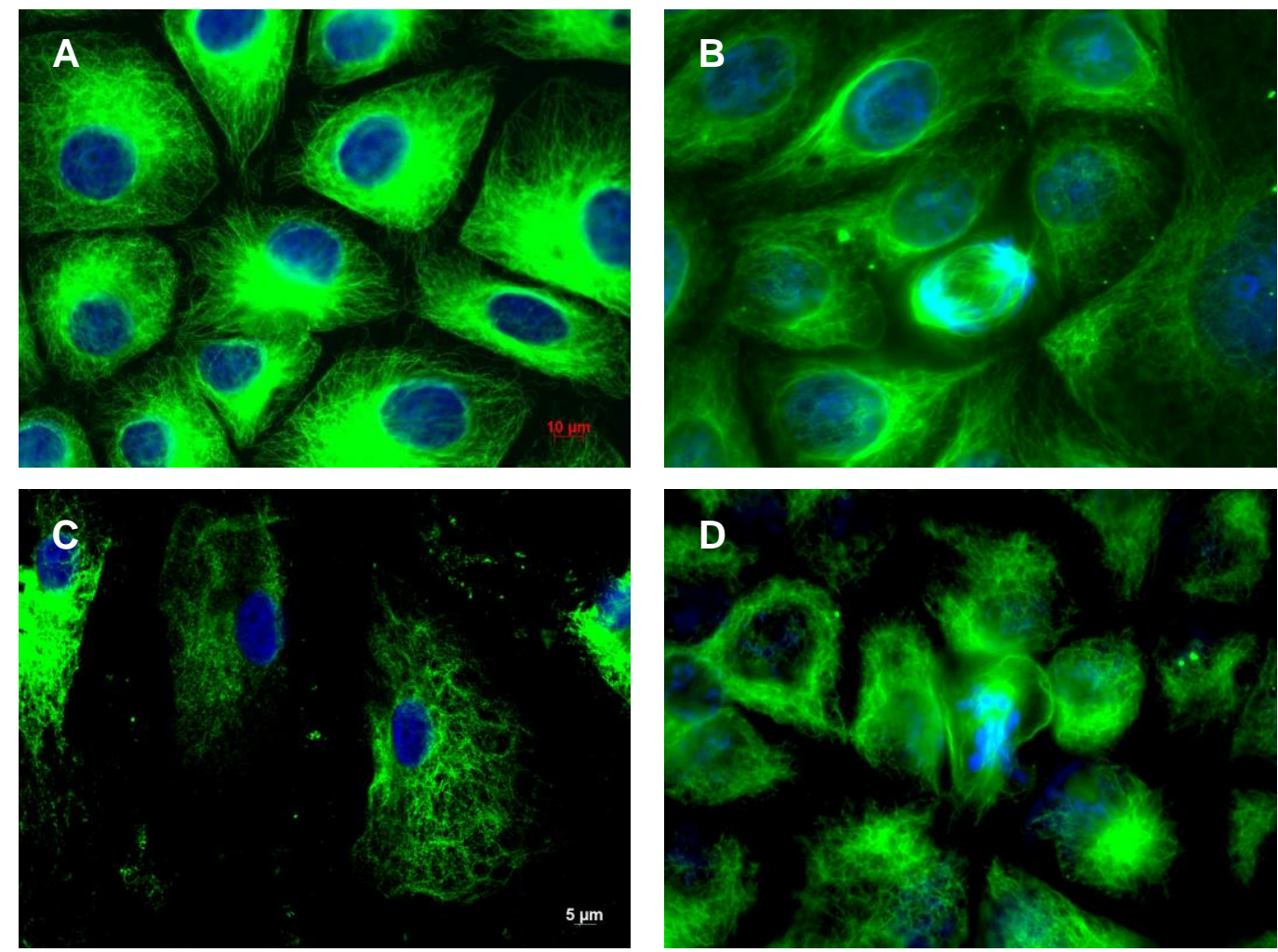

Figure 5. Effect of $\mathbf{1 1 a}$ and $\mathbf{2 2}$ on the microtubule cytoskeleton and mitotic spindle. PtK 2 cells were treated with 11a $\left(4 \mu \mathrm{g} \mathrm{mL}^{-1} ; \mathrm{C}\right)$ and $22\left(4 \mu \mathrm{g} \mathrm{mL}^{-1} ; \mathrm{D}\right)$ overnight and stained for microtubules (green) and DNA (blue). Control cells were incubated with methanol only (A and $\mathrm{B})$.

To further verify the effect of $\mathbf{1 1 a}$ and $\mathbf{2 2}$, tubulin polymerization assays were carried out in vitro (Figure 6). The effect of 11a and 22 was compared to that of methanol and nocodazole, a known inhibitor of tubulin polymerization. ${ }^{27}$ The basis of this assay is the incorporation of a fluorescent reporter into the developing microtubules. While nocodazole is only inhibiting the polymerization process, 11a and $\mathbf{2 2}$ induce a decrease in fluorescence. The effect of $\mathbf{2 2}$ was much stronger than that of $\mathbf{1 1 a}$, which still allowed a delayed tubulin polymerization. 


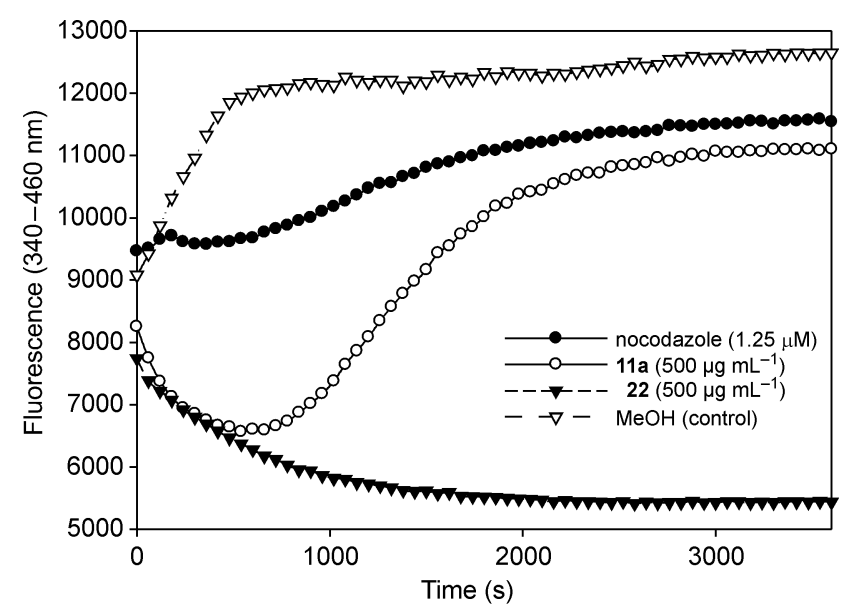

Figure 6. In vitro tubulin polymerization assay $\left(37^{\circ} \mathrm{C}\right)$. Compound $\mathbf{1 1 a}$ and $22(500 \mu \mathrm{g} \mathrm{mL}$ each) induced a decrease in fluorescence while the rate of tubulin polymerization progressed in the methanol control. While 11a still allowed some delayed polymerization, this process was completely blocked by 22. Fluorescence was monitored at $460 \mathrm{~nm}$ (excitation at $340 \mathrm{~nm}$ ).

We also checked for the influence of $11 a$ and 22 on the F-actin cytoskeleton, the microfilaments (Figure 7). Whereas compound 22 did not show a perturbing influence on the actin cytoskeleton (Figure 7D), this was indeed the case with 11a (Figure 7C).
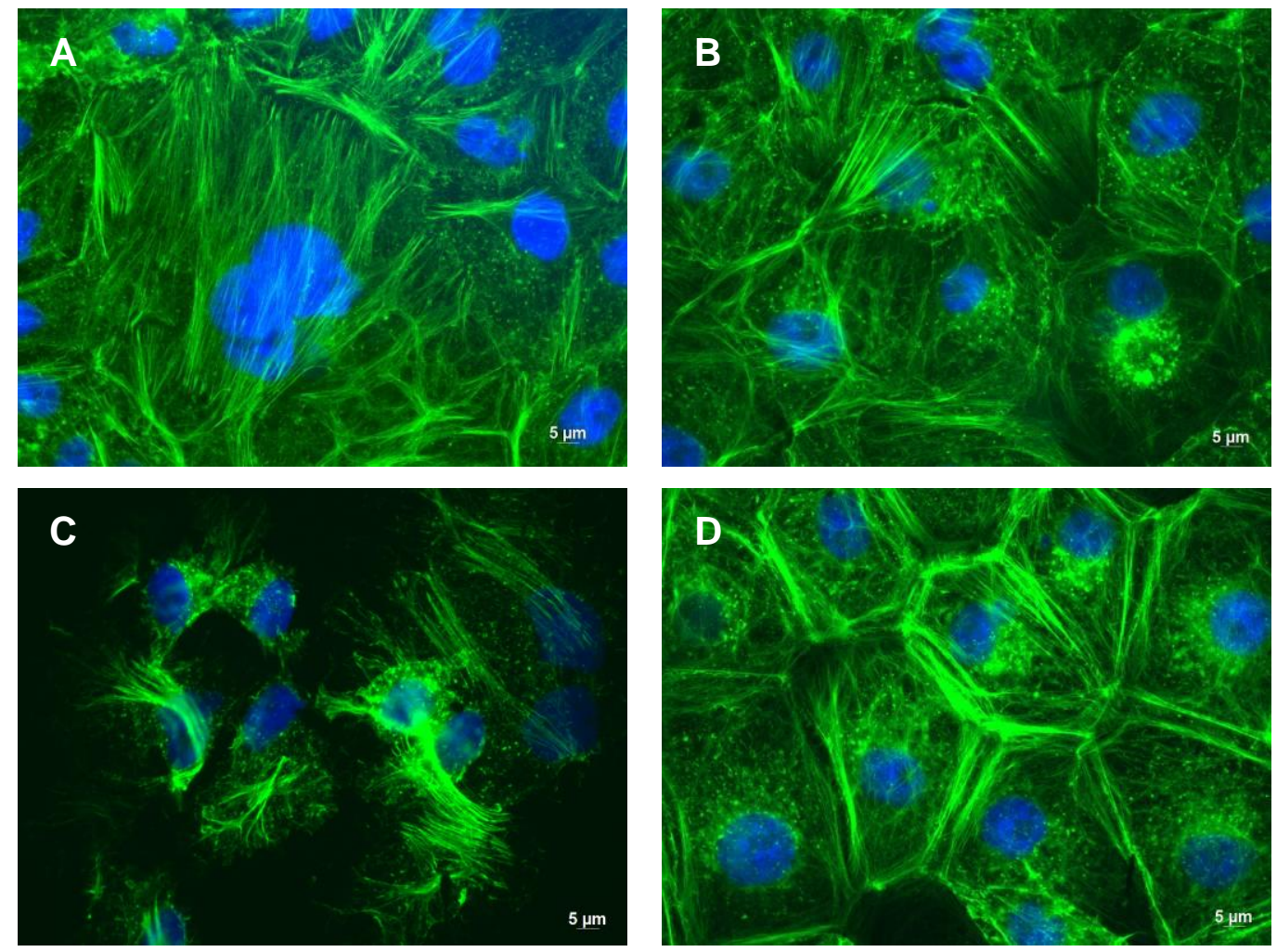

Figure 7. Effect of 11a and 22 on the F-actin cytoskeleton. $\mathrm{PtK}_{2}$ cells were incubated with 11a $\left(2 \mu \mathrm{g} \mathrm{mL}^{-1}\right.$; C) and $22\left(3 \mu \mathrm{g} \mathrm{mL}^{-1}\right.$; D) overnight and stained for F-actin (green) and DNA (blue). Control cells were treated with methanol only (A and B). 
For 11a, further studies were carried out that should possibly show co-localization with Factin. We used a "click chemistry" approach, which is based on a copper(I)-catalyzed azidealkyne cycloaddition $(\mathrm{CuAAC})$ reaction. ${ }^{28,29} \mathrm{PtK}_{2}$ cells were treated with terminal alkyne 11a $\left(3 \mu \mathrm{g} \mathrm{mL}{ }^{-1}\right)$ for $12 \mathrm{~h}$ and then fixed. The fixed cells were permeabilized with Triton X-100 and incubated with a click reagent mixture for $30 \mathrm{~min}$. Further staining for F-actin was carried out using fluorescently labeled phalloidin which binds selectively to F-actin. A blue fluorescence was observed that was co-localized with the green phalloidin label depicting the microfilaments.

In order to check the effect of 11a on actin in vitro, a polymerization assay with pyrene muscle actin was carried out, wherein the environmentally sensitive fluorophore pyrene indicates the polymerization state of actin. Thus, an increase in fluorescence is directly proportional to an increase in F-actin. As shown in Figure 8, an increase of the polymerization rate was measured with increasing concentration of 11a.

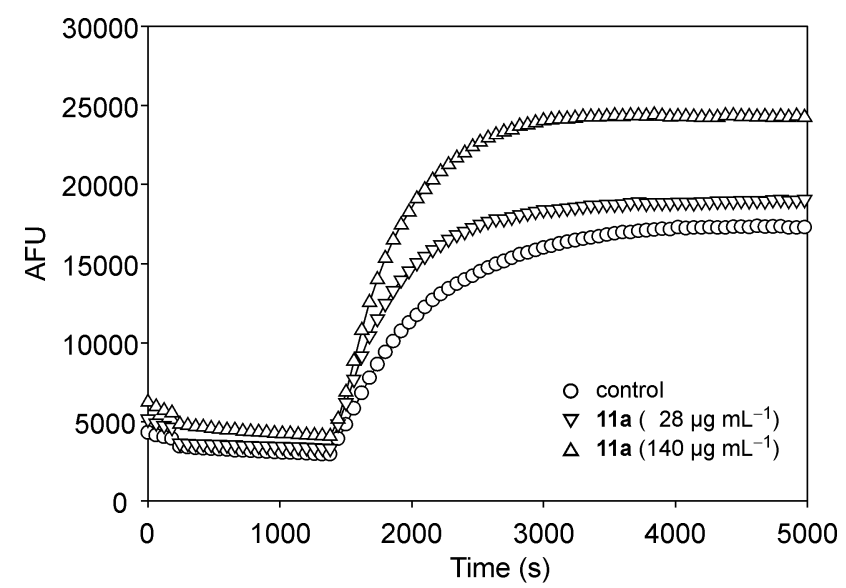

Figure 8. In vitro actin polymerization assay. Compound 11a induced an increased polymerization rate of pyrene actin in vitro. The actin fluorescence baseline was first read without any drug addition for $3 \mathrm{~min}$. Then methanol (control) and 11a (at different concentrations) were added and fluorescence read for a further $20 \mathrm{~min}$ to test if the drug itself has an effect before the polymerization reaction was started by addition of $10 \mathrm{X}$ actin polymerization buffer. Fluorescence was monitored at $420 \mathrm{~nm}$ (excitation $360 \mathrm{~nm}$ ).

\section{Conclusions}

We have synthesized a series of hydropentalene derivatives starting from hexahydropentalene-1,4-dione $(\mathbf{8})$, cis-tetrahydropentalene-2,5(1H,3H)-dione 7a (Weiss diketone) or its 3a,6a-dimethyl analogue $\mathbf{7 b}$. Hydropentalenes are not only biologically important parts of natural macrolactams but show pharmacophoric properties themselves as was demonstrated by biological studies. Their antitumor activities on mammalian cell lines varied with the substitution patterns. In the series of 1,4-dione $\mathbf{8}$ derived compounds $\mathbf{2 1 - 2 3}$ the presence of 
unsaturated rings seemed to play a key role. Consequently, the cytotoxicity against the tested L-929 cell line increased in the order saturated $21\left(\mathrm{IC}_{50}\right.$ ca. $\left.40 \mu \mathrm{M}\right)<$ single unsaturated 23 $\left(\mathrm{IC}_{50}\right.$ ca $\left.26 \mu \mathrm{M}\right)<$ double unsaturated $22\left(\mathrm{IC}_{50} 3 \mu \mathrm{M}\right)$. The latter was also most potent within all investigated compounds. In the Weiss diketone 7a based series, this structural element may be negligible although derivatives $\mathbf{1 7}$ and $\mathbf{1 8}$ displayed antiproliferative activities against L-929 cells comparable to $\mathbf{2 3}$. The most active compound in this group, however, was the alkyne 11a. A hierarchical cluster analysis of impedance monitoring data measured with 11a and 22 suggested a mode of action that might be similar to microtubule affecting compounds. During further investigations with 11a, tubulin and also actin could be identified as the probable target proteins. Both actin filaments and tubulin network in $\mathrm{PtK}_{2}$ cells were disturbed when treated with 11a, and in vitro experiments also showed that the polymerization of tubulin and of actin is impaired. With actin we measured an enhancing effect, with tubulin an inhibion of polymerization. An incubation of $\mathrm{PtK}_{2}$ cells with 22 only induced a perturbing effect on the microtubules, not on the microfilaments. Tubulin polymerization assays showed a strong inhibitory effect in vitro also. Future work should reveal whether pentalene-containing tetramic acid macrolactams 1-4 are indeed binding to the same target proteins or whether the tetramic acid moiety results in binding to a completely different target.

\section{Experimental}

\subsection{General}

NMR spectra were recorded on a Bruker Avance 500 spectrometer in $\mathrm{CDCl}_{3}$ with TMS as an internal standard. IR spectra were recorded on a Bruker FT-IR-spectrometer Vektor 22 with MKII golden gate single reflection Diamant ATR-system. Mass spectra were recorded on a Varian MAT 711 (EI, $70 \mathrm{eV}$ ) and a Bruker Daltonics micrOTOF_Q (ESI) with nitrogen as carrier gas. Optical rotations were measured with a Perkin-Elmer 241 polarimeter at $20{ }^{\circ} \mathrm{C}$. Flash chromatography was performed on silica gel, grain size 40-63 $\mu \mathrm{m}$ (Fluka). Moisturesensitive reactions were performed under nitrogen atmosphere in oven-dried glassware. All reagents were used as purchased unless otherwise noted. Solvents used for chromatography were distilled. THF was distilled from sodium/benzophenone, $\mathrm{CH}_{2} \mathrm{Cl}_{2}$ and toluene from $\mathrm{CaH}_{2}$. The reactions were monitored by TLC (Merck $60 \mathrm{~F}_{254}$ plates).

Cell lines were obtained from the German Collection of Microorganisms and Cell Cultures (DSMZ) or American Type Culture Collection (ATCC) and cultivated in the media recommended by the supplier at $37{ }^{\circ} \mathrm{C}$ and $10 \% \mathrm{CO}_{2}$. 


\section{2. (3a'R,6a'S)-5,5-Dimethylhexahydro-1'H-spiro[1,3-dioxane-2,2'-pentalen]-5'-yl pro- piolate (11a)}

A suspension of propiolic acid (248 mg, $3.52 \mathrm{mmol})$ and $\mathrm{PPh}_{3}(923 \mathrm{mg}, 3.52 \mathrm{mmol})$ in abs. $\mathrm{Et}_{2} \mathrm{O}(10 \mathrm{~mL})$ under $\mathrm{N}_{2}$ atmosphere was stirred for $15 \mathrm{~min}$. Then DEAD $(0.56 \mathrm{~mL}$, $3.52 \mathrm{mmol}$ ) was added followed by a solution of $\mathbf{1 0}^{18}(200 \mathrm{mg}, 0.88 \mathrm{mmol})$ in abs. $\mathrm{Et}_{2} \mathrm{O}$ $(5 \mathrm{~mL})$. The reaction mixture was stirred for $24 \mathrm{~h}$, filtered off, and the precipitate was washed with $\mathrm{Et}_{2} \mathrm{O}(15 \mathrm{~mL})$. The filtrate was concentrated and the residue purified by flash chromatography on $\mathrm{SiO}_{2}$ (hexanes/EtOAc, 20:1) to give 11a (98 mg, $0.35 \mathrm{mmol}, 40 \%$ ) as a white solid. $R_{\mathrm{f}} 0.40$ (hexanes/EtOAc, 10:1). ${ }^{1} \mathrm{H}$ NMR (500 MHz, $\left.\mathrm{CDCl}_{3}\right): \delta 0.96\left[\mathrm{~s}, 6 \mathrm{H}, \mathrm{C}\left(\mathrm{CH}_{3}\right)_{2}\right]$, 1.67-1.79 (m, 4H, 1'- $\left.\mathrm{H}_{\mathrm{a}}, 3^{\prime}-\mathrm{H}_{\mathrm{a}}, 4^{\prime}-\mathrm{H}_{\mathrm{a}}, 6^{\prime}-\mathrm{H}_{\mathrm{a}}\right), 1.98-2.07\left(\mathrm{~m}, 2 \mathrm{H}, 4^{\prime}-\mathrm{H}_{\mathrm{b}}, 6^{\prime}-\mathrm{H}_{\mathrm{b}}\right), 2.17$ (dd, $\left.J=13.5,8.9 \mathrm{~Hz}, 2 \mathrm{H}, 1^{\prime}-\mathrm{H}_{\mathrm{b}}, 3^{\prime}-\mathrm{H}_{\mathrm{b}}\right), 2.67-2.77$ (m, 2H, 3a'-H, 6a'-H), 2.83 (s, 1H, CCH), 3.46

$\left(\mathrm{s}, 2 \mathrm{H}, \mathrm{OCH}_{2}\right), 3.47\left(\mathrm{~s}, 2 \mathrm{H}, \mathrm{OCH}_{2}\right), 5.31-5.38\left(\mathrm{~m}, 1 \mathrm{H}, 5^{\prime}-\mathrm{H}\right) \mathrm{ppm} ;{ }^{13} \mathrm{C} \mathrm{NMR}(125 \mathrm{MHz}$, $\left.\mathrm{CDCl}_{3}\right): \delta 22.5\left[\mathrm{C}\left(\mathrm{CH}_{3}\right)_{2}\right], 30.1\left[C\left(\mathrm{CH}_{3}\right)_{2}\right], 38.2$ (C-3a', C-6a'), $39.0\left(\mathrm{C}^{\prime} 4^{\prime}, \mathrm{C}-6\right.$ '), $39.8(\mathrm{C}-1$ ', C-3'), 72.0, $72.1\left(\mathrm{OCH}_{2}\right), 74.0(\mathrm{CCH}), 75.1(\mathrm{CCH}), 80.9$ (C-5'), 110.0 (C-2), 152.4 [(CO)O] ppm; FT-IR (ATR): $\tilde{v}=3246$ (w), 2954 (m), 2865 (w), 2359 (w), 2112 (w), 1706 (s), 1472 (w), 1434 (w), 1395 (w), 1352 (w), 1334 (w), 1299 (w), 1233 (s), 1220 (vs), 1121 (s), 1105 (s), 1053 (m), $1011(\mathrm{~m}), 993$ (m), 966 (w), 943 (w), 926 (w), 905 (w), $877(\mathrm{w}), 792(\mathrm{w}), 758$ (m), $731(\mathrm{w}), 694(\mathrm{w}), 594(\mathrm{w}), 561(\mathrm{w}), 528(\mathrm{w}) \mathrm{cm}^{-1}$; MS (EI): $\mathrm{m} / z(\%)=278.2(61)[\mathrm{M}]^{+}$, 263.1 (2), 235.1 (10), 225.1 (8), 209.2 (56), 193.1 (26), 181.1 (7), 168.1 (72), 155.1 (19), 141.1 (9), 123.1 (36), 105.1 (4), 95.1 (23), 81.1 (17), 69.1 (100), 53.0 (30), 41.0 (44); HRMS (ESI): calcd. for $\mathrm{C}_{16} \mathrm{H}_{22} \mathrm{O}_{4} \mathrm{Na}^{+}[\mathrm{M}+\mathrm{Na}]^{+}$301.1410; found 301.1421 .

\section{3. (3aR,6aS)-5-\{[tert-Butyl(diphenyl)silyl]oxy\}octahydropentalen-2-ol (12)}

$\mathrm{NaBH}_{4}(90.0 \mathrm{mg}, 2.38 \mathrm{mmol})$ was added portionswise to a solution of $(3 \mathrm{a} R, 6 \mathrm{aS})-5-\{[$ tertbutyl(diphenyl)silyl]oxy $\}$ hexahydropentalen-2(1H)-one ${ }^{18}(300 \mathrm{mg}, 0.79 \mathrm{mmol})$ in dry $\mathrm{MeOH}$ $\left(40 \mathrm{~mL}\right.$ ) at $0{ }^{\circ} \mathrm{C}$ and the reaction mixture stirred at $0{ }^{\circ} \mathrm{C}$ for $2 \mathrm{~h}$. Then the reaction mixture was hydrolyzed with $\mathrm{H}_{2} \mathrm{O}(15 \mathrm{~mL})$, warmed to room temperature, and extracted with $\mathrm{Et}_{2} \mathrm{O}$ $(3 \times 20 \mathrm{~mL})$. The combined organic layers were washed with brine $(20 \mathrm{~mL})$ and dried $\left(\mathrm{MgSO}_{4}\right)$. After removal of the solvent under reduced pressure, $12(300 \mathrm{mg}, 0.79 \mathrm{mmol}$, quant.) was obtained as a colorless oil. ${ }^{1} \mathrm{H} \mathrm{NMR}\left(500 \mathrm{MHz}, \mathrm{CDCl}_{3}\right): \delta 0.96\left[\mathrm{~s}, 6 \mathrm{H}, \mathrm{C}\left(\mathrm{CH}_{3}\right)_{2}\right]$, 1.73-1.90 (m, 4H, 1'- $\left.\mathrm{H}_{\mathrm{a}}, 3^{\prime}-\mathrm{H}_{\mathrm{a}}, 4^{\prime}-\mathrm{H}_{\mathrm{a}}, 6^{\prime}-\mathrm{H}_{\mathrm{a}}\right), 2.15-2.33\left(\mathrm{~m}, 4 \mathrm{H}, 1^{\prime}-\mathrm{H}_{\mathrm{b}}, 3^{\prime}-\mathrm{H}_{\mathrm{b}}, 4^{\prime}-\mathrm{H}_{\mathrm{b}}, 6^{\prime}-\mathrm{H}_{\mathrm{b}}\right)$, 2.45-2.62 (m, 2H, 3a'-H, 6a'-H), 2.99 (s, 3H, SO $\left.\mathrm{SO}_{2}-\mathrm{CH}_{3}\right), 3.48$ [s, 4H, $\left.\left(\mathrm{OCH}_{2}\right)_{2}\right], 5.02$ (tt, $\left.J=6.7,5.9 \mathrm{~Hz}, 1 \mathrm{H}, 5^{\prime}-\mathrm{H}\right) \mathrm{ppm} ;{ }^{13} \mathrm{C} \mathrm{NMR}\left(75 \mathrm{MHz}, \mathrm{CDCl}_{3}\right): \delta 22.5\left[\mathrm{C}\left(\mathrm{CH}_{3}\right)\right], 22.6\left[\mathrm{C}\left(\mathrm{CH}_{3}\right)\right]$, 
30.1 (C-3a', C-6a'), 30.5 [C( $\left.\left.\mathrm{CH}_{3}\right)_{2}\right], 38.2\left(\mathrm{OCH}_{3}\right), 40.2$ (C-4'), 40.3 (C-6'), 48.3 (C-1', C-3'), $109.8\left[\left(\mathrm{OCH}_{2}\right)_{2}\right]$ ppm; FT-IR (ATR): $\tilde{v}=3071(\mathrm{w}), 2957(\mathrm{~m}), 2929(\mathrm{~m}), 2855(\mathrm{~m}), 1590(\mathrm{w})$, 1487 (w), 1471 (w), 1461 (w), 1427 (m), 1390 (w), 1360 (w), 1262 (w), 1188 (w), 1108 (vs), 1039 (m), 999 (m), 975 (w), 938 (w), 898 (w), 821 (m), 801 (w), 740 (m), 701 (vs), 610 (m) $\mathrm{cm}^{-1}$; MS (ESI): $m / z=403.21[\mathrm{M}+\mathrm{Na}]^{+}, 381.22[\mathrm{M}]^{+}, 365.19,248.09,226.95$; HRMS (ESI): calcd. for $\mathrm{C}_{24} \mathrm{H}_{32} \mathrm{O}_{2} \mathrm{SiNa}^{+}[\mathrm{M}+\mathrm{Na}]^{+}$403.2064; found 403.2074.

\section{4. (3aR,6aS)-5-\{[tert-Butyl(diphenyl)silyl]oxy\}octahydropentalen-2-yl propiolate (11b)}

As described for 11a, from propiolic acid (130 $\mu \mathrm{L}, 2.10 \mathrm{mmol}), \mathrm{PPh}_{3}(551 \mathrm{mg}, 2.10 \mathrm{mmol})$ in abs. $\mathrm{Et}_{2} \mathrm{O}(10 \mathrm{~mL}), \mathrm{DEAD}(0.33 \mathrm{~mL}, 2.10 \mathrm{mmol})$ and $12(200 \mathrm{mg}, 0.53 \mathrm{mmol})$ in abs. $\mathrm{Et}_{2} \mathrm{O}$ $\left(5 \mathrm{~mL}\right.$ ), flash chromatography on $\mathrm{SiO}_{2}$ (hexanes/EtOAc, 100:1, $R_{\mathrm{f}} 0.37$ ), colorless needles, yield: $84 \mathrm{mg}(0.35 \mathrm{mmol}, 37 \%) .{ }^{1} \mathrm{H} \mathrm{NMR}\left(500 \mathrm{MHz}, \mathrm{CDCl}_{3}\right): \delta 1.03$ [s, 9H, $\mathrm{C}_{\left.\left(\mathrm{CH}_{3}\right)_{3}\right], 1.45-}$ $1.52\left(\mathrm{~m}, 2 \mathrm{H}, 1^{\prime}-\mathrm{H}_{\mathrm{a}}, 3^{\prime}-\mathrm{H}_{\mathrm{a}}\right), 1.79-1.89\left(\mathrm{~m}, 2 \mathrm{H}, 1^{\prime}-\mathrm{H}_{\mathrm{b}}, 3^{\prime}-\mathrm{H}_{\mathrm{b}}\right), 1.92-2.07$ (m, 4H, 4'- $\mathrm{H}_{\mathrm{a}}, 6^{\prime}-\mathrm{H}_{\mathrm{a}}$, 4'- $\mathrm{H}_{\mathrm{b}}, 6$ '- $\mathrm{H}_{\mathrm{b}}$ ), 2.49-2.59 (m, 2H, 3a'-H, 6a'-H), 2.81 (s, 1H, CCH), 4.23 (dt, J=10.7, $5.4 \mathrm{~Hz}$, $\left.1 \mathrm{H}, 2^{\prime}-\mathrm{H}\right), 5.40-5.45\left(\mathrm{~m}, 1 \mathrm{H}, 5^{\prime} \mathrm{H}\right), 7.34-7.39(\mathrm{~m}, 4 \mathrm{H}, m-\mathrm{H}), 7.39-7.45$ (m, 2H, $\left.p-\mathrm{H}\right), 7.62-$ $\left.7.67(\mathrm{~m}, 4 \mathrm{H}, o-\mathrm{H}) \mathrm{ppm} ;{ }^{13} \mathrm{C} \mathrm{NMR}\left(125 \mathrm{MHz}, \mathrm{CDCl}_{3}\right): \delta 19.0\left[\mathrm{C}\left(\mathrm{CH}_{3}\right)_{3}\right], 26.9\left[\mathrm{C} \mathrm{CH}_{3}\right)_{3}\right], 39.4$ (C-3a', C-6a'), 39.7 (C-4', C-6'), 41.8 (C-1', C-3'), 73.9 (CCH), 75.2 (CCH), 81.5 (C-5'), $127.6(\mathrm{C}-m), 129.6(\mathrm{C}-p), 134.2$ [(CO)O], 135.8 (C-o) ppm; FT-IR (ATR): $\tilde{v}=3268(\mathrm{w})$, 3071 (w), 2962 (m), 2929 (w), 2856 (w), 2114 (w), 1711 (s), 1589 (w), 1472 (w), 1461 (w), 1427 (m), 1391 (w), 1373 (w), 1360 (w), 1304 (w), 1260 (s), 1262 (vs), 1175 (w), 1106 (vs), 1044 (s), 1019 (vs), 1001 (s), 940 (w), 902 (w), 861 (w), 820 (s), 798 (s), 758 (m), 740 (m), 701 (vs), 611 (m) $\mathrm{cm}^{-1}$; MS (ESI): $\mathrm{m} / z=455.20[\mathrm{M}+\mathrm{Na}]^{+}, 248.09$. HRMS (ESI): calcd. for $\mathrm{C}_{27} \mathrm{H}_{32} \mathrm{O}_{3} \mathrm{SiNa}^{+}[\mathrm{M}+\mathrm{Na}]^{+}$455.2013; found 455.2007.

\section{5. (1R,3aS,4R,5R,6aS)-5-\{[tert-Butyl(diphenyl)silyl]oxy\}-4-methyl-1-(3-methylbut-2- enyl)hexahydropentalen-2(1H)-one $(13 \mathrm{~d})$ and $(1 S, 3 \mathrm{a} S, 5 R, 6 R, 6 \mathrm{a} S)-5-\{[$ tert-butyl(diphe- nyl)silyl]oxy\}-6-methyl-1-(3-methylbut-2-enyl)hexahydropentalen-2(1H)-one (14d)}

According to GP1 in ref., ${ }^{19}$ from bis(1-phenylethyl)ammonium chloride $(213 \mathrm{mg}, 0.81$ mmol), BuLi (0.99 mL, $1.59 \mathrm{mmol}),(3 \mathrm{a} S, 4 R, 5 R, 6 \mathrm{a} R)-5-\{[$ tert-butyl(diphenyl)silyl]oxy $\}-4-$ methylhexahydropentalen-2(1H)-one $(266 \mathrm{mg}, 0.68 \mathrm{mmol})$ and prenyl bromide $(0.18 \mathrm{~mL}, 269$ mg, $1.60 \mathrm{mmol}$ ). 13d: colorless oil, yield: $113 \mathrm{mg}$ (36\%), $R_{\mathrm{f}} 0.46$ (hexanes/EtOAc, 15:1), $[\alpha]_{\mathrm{D}}^{20}-52.7\left(c=5.1, \mathrm{CH}_{2} \mathrm{Cl}_{2}\right) .{ }^{1} \mathrm{H} \mathrm{NMR}\left(500 \mathrm{MHz}, \mathrm{CDCl}_{3}\right): \delta 0.86(\mathrm{~d}, J=6.8 \mathrm{~Hz}, 3 \mathrm{H}, 4-$ $\left.\mathrm{CH}_{3}\right), 1.05\left[\mathrm{~s}, 9 \mathrm{H}, \mathrm{SiC}\left(\mathrm{CH}_{3}\right)_{3}\right], 1.51\left(\mathrm{ddd}, J=13.6,7.0,4.7 \mathrm{~Hz}, 1 \mathrm{H}, 6-\mathrm{H}_{\mathrm{a}}\right), 1.60(\mathrm{q}, J=1.2 \mathrm{~Hz}$, 
$3 \mathrm{H}, 4^{\prime}-\mathrm{H}$ or $\left.5^{\prime}-\mathrm{H}\right), 1.65$ (q, $J=1.2 \mathrm{~Hz}, 3 \mathrm{H}, 4^{\prime}-\mathrm{H}$ or 5'-H), 1.71 (ddq, $J=9.2,7.0,6.8 \mathrm{~Hz}, 1 \mathrm{H}$, 4-H), 1.96 (dq, $J=9.1,3.9 \mathrm{~Hz}, 1 \mathrm{H}, 3 \mathrm{a}-\mathrm{H}), 2.00-2.07$ (m, 1H, 1'- $\mathrm{H}_{\mathrm{a}}$ ), 2.03 (ddd, $J=13.6,8.5$, $\left.7.0 \mathrm{~Hz}, 1 \mathrm{H}, 6-\mathrm{H}_{\mathrm{b}}\right), 2.15$ (dq, $\left.J=8.5,4.7 \mathrm{~Hz}, 1 \mathrm{H}, 6 \mathrm{a}-\mathrm{H}\right), 2.18-2.24$ (m, 1H, 1-H), 2.28 (ddd, $J$ $\left.=19.1,3.9,1.6 \mathrm{~Hz}, 1 \mathrm{H}, 3-\mathrm{H}_{\mathrm{a}}\right), 2.31-2.38\left(\mathrm{~m}, 1 \mathrm{H}, 1\right.$ '- $\left.-\mathrm{H}_{\mathrm{b}}\right), 2.36(\mathrm{dd}, J=19.1,9.3 \mathrm{~Hz}, 1 \mathrm{H}, 3-$ $\mathrm{H}_{\mathrm{b}}$ ), 3.80 (q, $\left.J=7.0 \mathrm{~Hz}, 1 \mathrm{H}, 5-\mathrm{H}\right), 4.98-5.04$ (m, 1H, 2'-H), 7.35-7.39 (m, 4H, $\left.m-\mathrm{H}, m^{\prime}-\mathrm{H}\right)$, 7.41-7.45 (m, 2H, p-H, p'-H), 7.63-7.68 (m, 4H,o-H,o'-H) ppm; ${ }^{13} \mathrm{C}$ NMR $(125 \mathrm{MHz}$,

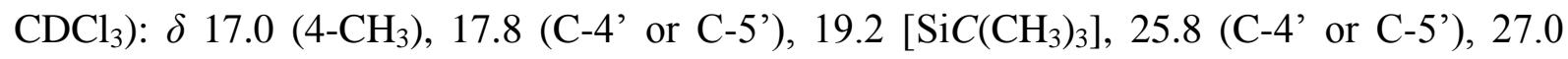
[SiC $\left.\left(\mathrm{CH}_{3}\right)_{3}\right], 28.5\left(\mathrm{C}-1^{\prime}\right), 41.4(\mathrm{C}-6), 42.4$ (C-6a), 42.6 (C-3, C-3a), 49.2 (C-4), 56.3 (C-1), 81.6 (C-5), 121.1 (C-2’), 127.5, 127.6 (C-m, C-m’), 129.61, 129.62 (C-p, C-p’), 133.3 (C-3'), 134.1, 134.4 (C-i, C-i'), 135.90 (C-o, C-o'), 221.4 (C-2) ppm; FT-IR (ATR): $\tilde{v}=3071(\mathrm{w})$, 2958 (s), 2929 (s), 2858 (m), 1737 (vs), 1589 (w), 1460 (m), 1428 (m), 1378 (w), 1110 (vs), $1033(\mathrm{~m}), 874(\mathrm{~m}), 822(\mathrm{~m}), 740(\mathrm{~m}), 702$ (s), $613(\mathrm{~m}), 548$ (w), $526(\mathrm{w}) \mathrm{cm}^{-1}$; MS (ESI): $\mathrm{m} / \mathrm{z}$ $=483.3[\mathrm{M}+\mathrm{Na}]^{+}, 461.3,383.2\left[\mathrm{M}+\mathrm{Na}-\mathrm{C}_{6} \mathrm{H}_{6}\right]^{+}$, 205.2, 187.2, 86.1; HRMS (ESI): calcd. for $\mathrm{C}_{30} \mathrm{H}_{40} \mathrm{O}_{2} \mathrm{SiNa}^{+}[\mathrm{M}+\mathrm{Na}]^{+}$483.2692; found 483.2692. 14d: colorless oil, yield: $64 \mathrm{mg}$ (20\%), $R_{\mathrm{f}} 0.46$ (hexanes/EtOAc, 15:1), $[\alpha]_{\mathrm{D}}^{20}-4.0\left(c=4.1, \mathrm{CH}_{2} \mathrm{Cl}_{2}\right) .{ }^{1} \mathrm{H}$ NMR $(500 \mathrm{MHz}$, $\left.\mathrm{CDCl}_{3}\right): \delta 0.82\left(\mathrm{~d}, J=6.6 \mathrm{~Hz}, 3 \mathrm{H}, 6-\mathrm{CH}_{3}\right), 1.04\left[\mathrm{~s}, 9 \mathrm{H}, \mathrm{SiC}\left(\mathrm{CH}_{3}\right)_{3}\right], 1.50(\mathrm{dq}, J=13.3$, $6.6 \mathrm{~Hz}, 1 \mathrm{H}, 4-\mathrm{H}_{\mathrm{a}}$ ), 1.58 (q, $J=1.1 \mathrm{~Hz}, 3 \mathrm{H}, 4^{\prime}-\mathrm{H}$ or 5'-H), 1.67 (q, $J=1.1 \mathrm{~Hz}, 3 \mathrm{H}, 4^{\prime}-\mathrm{H}$ or 5'H), 1.77-1.86 (m, 2H, 6a-H, 6-H), 2.04-2.11 (m, 2H, 1'- $\left.\mathrm{H}_{\mathrm{a}}, 4-\mathrm{H}\right), 2.20-2.35$ (m, 3H, 1-H, 1'$\mathrm{H}_{\mathrm{b}}, 3-\mathrm{H}_{\mathrm{a}}$ ), 2.43-2.49 (m, 2H, 3a-H, 3- $\mathrm{H}_{\mathrm{b}}$ ), 3.80 (q, $\left.J=6.4 \mathrm{~Hz}, 1 \mathrm{H}, 5-\mathrm{H}\right), 5.02-5.07(\mathrm{~m}, 1 \mathrm{H}$, 2'-H), 7.35-7.39 (m, 4H, m-H, m'-H), 7.41-7.45 (m, 2H, p-H, p'-H), 7.62-7.68 (m, 4H, o-H, $\left.o^{\prime}-\mathrm{H}\right) \mathrm{ppm} ;{ }^{13} \mathrm{C} \mathrm{NMR}\left(125 \mathrm{MHz}, \mathrm{CDCl}_{3}\right): \delta 17.6\left(6-\mathrm{CH}_{3}\right), 17.8$ (C-4' or C-5'), 19.1 [SiC $\left(\mathrm{CH}_{3}\right)_{3}$ ], 25.8 (C-4' or C-5'), 27.0 [SiC $\left(\mathrm{CH}_{3}\right)_{3}$ ], 29.4 (C-1'), 33.9 (C-3a), 42.0 (C-4), 45.2 (C-3), 49.0 (C-6), 51.0 (C-6a), 54.4 (C-1), 81.8 (C-5), 121.3 (C-2'), 127.53, 127.54 (C-m, C$m^{\prime}$ ), 129.59, 129.61 (C-p, C-p'), 133.4 (C-3'), 134.1, 134.3 (C-i, C-i'), 135.87, 135.91 (C-o, C-o'), 222.0 (C-2) ppm; FT-IR (ATR): $\tilde{v}=3070$ (w), 2956 (s), 2930 (s), 2860 (m), 1736 (vs), 1454 (w), 1429 (w), 1380 (w), 1110 (vs), 867 (w), 821 (w), 740 (m), 703 (s), 613 (m),

$504(\mathrm{~m}) \mathrm{cm}^{-1}$; MS (ESI): $\mathrm{m} / z=483.3[\mathrm{M}+\mathrm{Na}]^{+}, 461.3,383.2\left[\mathrm{M}+\mathrm{Na}-\mathrm{C}_{6} \mathrm{H}_{6}\right]^{+}, 205.2$, 187.2, 86.1; HRMS (ESI): calcd. for $\mathrm{C}_{30} \mathrm{H}_{40} \mathrm{O}_{2} \mathrm{SiNa}^{+}[\mathrm{M}+\mathrm{Na}]^{+}$483.2692; found 483.2683.

\section{6. $\{[(2 R, 3 R, 3 \mathrm{a} S, 4 R, 6 \mathrm{a} R)-3-$ Allyl-4-methyl-1,2,3,3a,4,6a-hexahydropentalen-2-yl]oxy $\}$ - (tert-butyl)diphenylsilane (18)}

In analogy to ref., ${ }^{19}$ a $1.6 \mathrm{M}$ solution of $n$-BuLi in hexane $(0.29 \mathrm{~mL}, 460 \mu \mathrm{mol})$ was slowly added dropwise to a solution of $\mathbf{1 6 b}(115 \mathrm{mg}, 190 \mu \mathrm{mol})$ in abs. THF (5 mL) and TMEDA $(0.5 \mathrm{~mL})$ at $-78^{\circ} \mathrm{C}$. Then the reaction mixture was warmed to room temperature and stirred 
for $2.5 \mathrm{~h}$. A satd $\mathrm{NaHCO}_{3}$ solution (4 mL) was added, the organic solvent removed and the remaining aqueous layer extracted with $\mathrm{CH}_{2} \mathrm{Cl}_{2}(3 \times 30 \mathrm{~mL})$. The combined extracts were dried $\left(\mathrm{MgSO}_{4}\right)$ and concentrated. The residue was purified by flash chromatography on $\mathrm{SiO}_{2}$ (hexanes/EtOAc, $\left.10: 1, R_{\mathrm{f}} 0.91\right)$ to give $\mathbf{1 8}\left(67.0 \mathrm{mg}, 85 \%\right.$, purity $>95 \%$ by ${ }^{1} \mathrm{H} \mathrm{NMR}$ ) as a yellowish oil. $[\alpha]_{\mathrm{D}}^{20}-14.6\left(c=1.0, \mathrm{CH}_{2} \mathrm{Cl}_{2}\right) .{ }^{1} \mathrm{H} \mathrm{NMR}\left(500 \mathrm{MHz}, \mathrm{CDCl}_{3}\right): \delta 0.94(\mathrm{~d}, J=$ $\left.6.9 \mathrm{~Hz}, 3 \mathrm{H}, 4-\mathrm{CH}_{3}\right), 1.04$ [s, 9H, $\left.\mathrm{SiC}\left(\mathrm{CH}_{3}\right)_{3}\right], 1.25\left(\mathrm{dt}, J=12.2,8.6 \mathrm{~Hz}, 1 \mathrm{H}, 1-\mathrm{H}_{\mathrm{a}}\right), 1.61$ (dt, $J$ $=2.5,8.9 \mathrm{~Hz}, 1 \mathrm{H}, 3 \mathrm{a}-\mathrm{H}), 1.70(\mathrm{ddt}, J=12.9,8.6,4.4 \mathrm{~Hz}, 1 \mathrm{H}, 3-\mathrm{H}), 1.84$ (ddd, $J=12.2,8.6$, $\left.6.4 \mathrm{~Hz}, 1 \mathrm{H}, 1-\mathrm{H}_{\mathrm{b}}\right), 1.87-1.91\left(\mathrm{~m}, 1 \mathrm{H}, 1^{\prime}-\mathrm{H}_{\mathrm{a}}\right), 2.36-2.42\left(\mathrm{~m}, 1 \mathrm{H}, 1^{\prime}-\mathrm{H}_{\mathrm{b}}\right), 2.51-2.57(\mathrm{~m}, 1 \mathrm{H}, 4-$ H), 2.80-2.87 (m, 1H, 6a-H), $3.67(\mathrm{dt}, J=6.4,8.6 \mathrm{~Hz}, 1 \mathrm{H}, 2-\mathrm{H}), 4.90-4.98(\mathrm{~m}, 2 \mathrm{H}, 3$ '-H), $5.47(\mathrm{dt}, J=5.5,2.2 \mathrm{~Hz}, 1 \mathrm{H}, 5-\mathrm{H}), 5.52(\mathrm{dt}, J=5.5,2.0 \mathrm{~Hz}, 1 \mathrm{H}, 6-\mathrm{H}), 5.71$ (dddd, $J=14.5$, 10.1, 7.7, $\left.6.8 \mathrm{~Hz}, 1 \mathrm{H}, 2^{\prime}-\mathrm{H}\right), 7.34-7.38$ (m, 4H, m-H, m'-H), 7.39-7.44 (m, 2H, p-H, p'-H), 7.64-7.69 (m, 4H, o-H, o'-H) ppm; $\left.\left.{ }^{13} \mathrm{C} \mathrm{NMR} \mathrm{(125} \mathrm{MHz,} \mathrm{CDCl}_{3}\right): \delta 19.2[\mathrm{SiC} \text { (CH})_{3}\right)_{3}, 21.5$ (4- $\left.\mathrm{CH}_{3}\right), 27.0$ [ $\left.\mathrm{SiC}\left(\mathrm{CH}_{3}\right)_{3}\right], 37.0(\mathrm{C}-1$ '), 39.8 (C-1), 45.5 (C-6a), 46.8 (C-4), 51.4 (C-3a), 53.7 (C-3), 78.3 (C-2), 115.5 (C-3’), 127.4, 127.5 (C-m, C-m'), 129.4, 129.5 (C-p, C-p'), 133.5 (C6), 134.2 (C-5), 134.3, 134.7 (C-i, C-i'), 136.0 (C-o, C-o'), 137.5 (C-2’) ppm; FT-IR (ATR): $\tilde{v}=3050(\mathrm{w}), 2953(\mathrm{~m}), 2928(\mathrm{~m}), 2859(\mathrm{~m}), 2359(\mathrm{w}), 1640(\mathrm{w}), 1427(\mathrm{w}), 1373(\mathrm{w}), 1264$ (s), 1109 (s), 997 (w), 909 (m), 866 (w), 822 (w), 734 (vs), 701 (vs), 612 (m) cm ; $^{-1}$ MS (EI): $m / z(\%)=401.2(8)[\mathrm{M}-\mathrm{Me}]^{+}, 359.2$ (100) $[\mathrm{M}-t-\mathrm{Bu}]^{+}, 281.1$ (21), 199.1 (68); HRMS (ESI): calcd. for $\mathrm{C}_{28} \mathrm{H}_{36} \mathrm{OsiNa}^{+}[\mathrm{M}+\mathrm{Na}]^{+}$439.2428; found 439.2427.

\section{7. tert-Butyl(diphenyl)[(3a' $\left.S, 6 a^{\prime} S\right)-3$ ',3a',6',6a'-tetrahydro-2' $H$-spiro[1,3-dioxolane- 2,1'-pentalen]-4'-yloxy]silane (20)}

A solution of $19(72.0 \mathrm{mg}, 0.22 \mathrm{mmol})$ in THF $(2 \mathrm{~mL})$ was slowly added dropwise to a solution of KHMDS $(64.0 \mathrm{mg}, 0.22 \mathrm{mmol})$ in THF $(3 \mathrm{~mL})$ at $-78{ }^{\circ} \mathrm{C}$ and the mixture stirred for $20 \mathrm{~min}$. After addition of TBDPSCl $(76.0 \mu \mathrm{L}, 72.0 \mathrm{mg}, 0.24 \mathrm{mmol})$, the reaction mixture was allowed to warm to room temperature and stirred for a further $1 \mathrm{~h}$. The solvent was removed under vacuum, the residue taken up with pentane and filtered through Celite. The filtrate was concentrated under vacuum and the crude product purified by chromatography on $\mathrm{SiO}_{2}$ with hexanes/EtOAc $\left(10: 1, R_{\mathrm{f}} 0.75\right)$ to give $20(72.0 \mathrm{mg}, 0.17 \mathrm{mmol}, 85 \%) .{ }^{1} \mathrm{H} \mathrm{NMR}$ $\left(500 \mathrm{MHz}, \mathrm{CDCl}_{3}\right): \delta 1.03$ [s, 9H, $\left.\mathrm{SiC}\left(\mathrm{CH}_{3}\right)_{3}\right], 1.58-1.62\left(\mathrm{~m}, 2 \mathrm{H}, 2^{\prime}-\mathrm{H}\right), 1.70-1.77(\mathrm{~m}, 1 \mathrm{H}$, 3'- $\mathrm{H}_{\mathrm{a}}$ ), 1.89-1.93 (m, 1H, 3'- $\mathrm{H}_{\mathrm{b}}$ ), 2.12-2.16 (m, 2H, 6'-H), 2.41-2.45 (m, 1H, 6a'-H), 3.01$3.13\left(\mathrm{~m}, 1 \mathrm{H}, 3 \mathrm{a}^{\prime}-\mathrm{H}\right), 3.75-3.80\left(\mathrm{~m}, 1 \mathrm{H}, \mathrm{OCH}_{2}\right), 3.83-3.87\left(\mathrm{~m}, 3 \mathrm{H}, \mathrm{OCH}_{2}\right), 4.07-4.09(\mathrm{~m}, 1 \mathrm{H}$, 5'-H), 7.36-7.41 (m, 4H,o-H), 7.42-7.45 (m, 2H, p-H), 7.68-7.71 (m, 4H, m-H) ppm; ${ }^{13} \mathrm{C}$ NMR (125 MHz, $\left.\mathrm{CDCl}_{3}\right): \delta 19.9\left[\mathrm{SiC}\left(\mathrm{CH}_{3}\right)_{3}\right], 26.4\left(\mathrm{C}-3\right.$ ') $26.8\left[\mathrm{SiC}\left(\mathrm{CH}_{3}\right)_{3}\right], 30.0(\mathrm{C}-6$ '), 
32.9 (C-2'), 45.2 (C-6a'), 48.8 (C-3a'), $63.9\left(\mathrm{OCH}_{2}\right), 65.2\left(\mathrm{OCH}_{2}\right), 102.9\left(\mathrm{C}-5{ }^{\prime}\right), 119.8(\mathrm{C}-$ 1'), 128.1 (C-o) , 130.2 (C-p), $133.4(\mathrm{C}-i), 135.9$ (C-m) ppm; FT-IR (ATR): $\tilde{v}=3071(\mathrm{w})$, 2955 (s), 2941 (s), 2889 (m), 2858 (s), 2357 (w), 1650 (s), 1588 (w), 1472 (m), 1428 (m), 1391 (w), 1348 (s), 1302 (m), 1269 (m), 1239 (m), 1202 (s), 1183 (m), 1109 (vs), 1030 (s), 1009 (m), 946 (s), 889 (w), 861 (m), 840 (s), 822 (s), 794 (m), 741 (m), 701 (vs), 651 (w), 613 (m), $574(\mathrm{w}) \mathrm{cm}^{-1}$; MS (ESI): $\mathrm{m} / z=443.20[\mathrm{M}+\mathrm{Na}]^{+}, 421.22[\mathrm{M}+\mathrm{H}]^{+}, 358.15,304.26$, 282.27, 239.11; HRMS (ESI): calcd. for $\mathrm{C}_{26} \mathrm{H}_{32} \mathrm{O}_{3} \mathrm{Si}[\mathrm{M}+\mathrm{H}]^{+}$420.2193; found 420.2199.

\section{8. (3a' $\left.S, 4^{\prime} R, 5^{\prime} R, 6 a^{\prime} S\right)$ - and (3a' $\left.S, 4^{\prime} S, 5^{\prime} S, 6 a^{\prime} S\right)$-4'-\{[tert-Butyl(diphenyl)silyl]oxy $\}$ hexa- hydro-2' $H$-spiro[1,3-dioxolane-2,1'-pentalen]-5'-ol (21a) and (21b)}

a) Silyl enol ether 20 (210 mg, $0.50 \mathrm{mmol})$ was added to a solution of MeCN (2.4 mL), dimethoxymethane $(4.80 \mathrm{~mL})$ and stock solution I $(4.80 \mathrm{~mL})$ [prepared from sodium tetraborate decahydrate $(19.1 \mathrm{~g}, 50.0 \mathrm{mmol})$ and disodium ethylenediaminetetraacetate dihydrate (149 $\mathrm{mg}, 0.40 \mathrm{mmol})$ in $\mathrm{H}_{2} \mathrm{O}(1 \mathrm{~L})$ ] at $0{ }^{\circ} \mathrm{C}$ followed by addition of Shi catalyst $(50.0 \mathrm{mg}, 0.20$ mmol) and $\mathrm{Bu}_{4} \mathrm{NHSO}_{4}(61.7 \mathrm{mg}, 0.20 \mathrm{mmol})$. To this reaction mixture ice-cold solutions of oxone (427 mg, $0.70 \mathrm{mmol})$ in stock solution II (3 mL) [prepared from disodium ethylenediaminetetraacetate dihydrate $(149 \mathrm{mg}, 0.40 \mathrm{mmol})$ in $\left.\mathrm{H}_{2} \mathrm{O}(1 \mathrm{~L})\right]$ and $\mathrm{K}_{2} \mathrm{CO}_{3}(402 \mathrm{mg}, 2.80$ mmol) in $\mathrm{H}_{2} \mathrm{O}(3 \mathrm{~mL})$ were added successively over $2 \mathrm{~h}$. After complete addition, the twophase mixture was stirred at $0{ }^{\circ} \mathrm{C}$ for a further $3 \mathrm{~h}$ and diluted with $\mathrm{H}_{2} \mathrm{O}(30 \mathrm{~mL})$ to dissolve the precipitated salts. The layers were separated and the aqueous layer was extracted with $\mathrm{CH}_{2} \mathrm{Cl}_{2}(3 \times 30 \mathrm{~mL})$. The combined organic layers were washed with brine, dried $\left(\mathrm{MgSO}_{4}\right)$ and concentrated under vacuum to $5 \mathrm{~mL}$. Crude tert-butyl[(1b'S,4a' $S)$-hexahydro-1a' $H$ spiro[1,3-dioxalane-2,4'-pentaleno[1,2-b]oxiren]-1a'-yloxy]diphenylsilane was used without further purification.

b) To a solution of crude tert-butyl[(1a' $\left.R, 1 \mathrm{~b}^{\prime} S, 4 \mathrm{a}^{\prime} S\right)$-hexahydro-1a' $H$-spiro[1,3-dioxolane2,4'-pentaleno[1,2-b]-1a'-yloxy]diphenylsilane $(0.25 \mathrm{mmol})$ in $\mathrm{THF}(2 \mathrm{~mL})$ at $0{ }^{\circ} \mathrm{C}$ was added $\mathrm{BH}_{3}$. THF (0.64 mL, $0.64 \mathrm{mmol}, 1.0 \mathrm{M}$ in THF) and the reaction mixture stirred for $1 \mathrm{~h}$. After complete conversion (GC control), a 1 M tris(hydroxymethyl)aminomethane hydrochloride solution $(5 \mathrm{~mL})$ was added (gas formation!). The bilayer system was warmed to room temperature and stirred for $30 \mathrm{~min}$. The layers were separated and the aqueous layer was extracted with EtOAc $(3 \times 10 \mathrm{~mL})$. The combined organic layers were dried $\left(\mathrm{MgSO}_{4}\right)$ and the solvent removed under vacuum. The residue was purified by chromatography on $\mathrm{SiO}_{2}$ (hexanes/EtOAc, $4: 1 \rightarrow 3: 1 \rightarrow 2.5: 1)$ to give $21 \mathbf{a}(14 \mathrm{mg}, 15 \%), \mathbf{2 1 b}(38 \mathrm{mg}, 38 \%)$ and the respec- 
tive cis-compound (19 mg, 19\%). 21a: $R_{\mathrm{f}} 0.8$ (hexanes/EtOAc, 2:1). ${ }^{1} \mathrm{H}$ NMR $(500 \mathrm{MHz}$, $\left.\mathrm{CDCl}_{3}\right): \delta 1.10\left(\mathrm{~s}, 9 \mathrm{H}, \mathrm{SiC}\left(\mathrm{CH}_{3}\right)_{3}\right), 1.53-1.59\left(\mathrm{~m}, 1 \mathrm{H}, 3^{\prime}-\mathrm{H}_{\mathrm{a}}\right), 1.59-1.62\left(\mathrm{~m}, 1 \mathrm{H}, 2^{\prime}-\mathrm{H}_{\mathrm{a}}\right), 1.68-$ $1.74\left(\mathrm{~m}, 1 \mathrm{H}, 6^{\prime}-\mathrm{H}_{\mathrm{a}}\right), 1.87-1.91\left(\mathrm{~m}, 1 \mathrm{H}, 6^{\prime}-\mathrm{H}_{\mathrm{b}}\right), 2.10-2.16\left(\mathrm{~m}, 1 \mathrm{H}, 3^{\prime}-\mathrm{H}_{\mathrm{b}}\right), 2.16-2.24(\mathrm{~m}, 2 \mathrm{H}$, 2'- $\mathrm{H}_{\mathrm{b}}, 6 \mathrm{a}$ '-H), 2.41-2.47 (m, 1H, 3a'-H), 2.78-2.80 (d, $\left.J=2.9 \mathrm{~Hz}, 1 \mathrm{H}, \mathrm{OH}\right), 3.82-3.85$ (m, $\left.1 \mathrm{H}, 5^{\prime}-\mathrm{H}\right), 3.87-3.94\left(\mathrm{~m}, 4 \mathrm{H}, \mathrm{OCH}_{2} \mathrm{CH}_{2} \mathrm{O}\right), 4.05-4.08\left(\mathrm{~m}, 1 \mathrm{H}, 4^{\prime}-\mathrm{H}\right), 7.36-7.49(\mathrm{~m}, 4 \mathrm{H}, o-\mathrm{H})$, 7.42-7.46 (m, 2H, $p-\mathrm{H}), 7.66-7.71(\mathrm{~m}, 4 \mathrm{H}, m-\mathrm{H}) \mathrm{ppm} ;{ }^{13} \mathrm{C} \mathrm{NMR}\left(125 \mathrm{MHz}, \mathrm{CDCl}_{3}\right): \delta 19.4$ $\left(\mathrm{SiC}\left(\mathrm{CH}_{3}\right)_{3}\right), 22.3\left(\mathrm{C}-3^{\prime}\right), 27.1\left(\mathrm{SiC}\left(\mathrm{CH}_{3}\right)_{3}\right), 31.8$ (C-6'), 33.6 (C-2'), 44.2 (C-3a'), 46.9 (C6a'), $64.0\left(\mathrm{OCH}_{2} \mathrm{CH}_{2} \mathrm{O}\right), 64.9\left(\mathrm{OCH}_{2} \mathrm{CH}_{2} \mathrm{O}\right), 74.0$ (C-5'), 77.2 (C-4'), 119.4 (C-1'), 127.7 (C$o), 127.8(\mathrm{C}-o), 129.87$ (C-p), 129.94 (C-p), 133.4 (C-i), 133.6 (C-i), 135.6 (C-o), 135.7 (C-o) ppm; FT-IR (ATR): $\tilde{v}=2952$ (m), 2889 (m), 2858 (m), $1472(\mathrm{w}), 1428(\mathrm{w}), 1362$ (w), 1332 (w), 1213 (w), 1110 (vs), 1031 (m), 903 (vs), 854 (w), 822 (w), 729 (vs), 703 (vs), 649 (m), $614(\mathrm{w}), 537(\mathrm{~m}) \mathrm{cm}^{-1}$; MS (ESI): $\mathrm{m} / z=461.21[\mathrm{M}+\mathrm{Na}]^{+}, 439.23[\mathrm{M}+\mathrm{H}]^{+}, 361.18[\mathrm{M}-$ $\mathrm{Ph}]^{+}, 331.14,317.16,283.14,265.12,239.11\left[\mathrm{M}-\mathrm{TBDPS}^{+}\right.$, 211.08, 197.06, 165.09, 155.09, 121.06; HRMS (ESI): calcd. for $\mathrm{C}_{26} \mathrm{H}_{34} \mathrm{O}_{4} \mathrm{SiNa}^{+}[\mathrm{M}+\mathrm{Na}]^{+}$461.2119; found 461.2117. 21b: $R_{\mathrm{f}} 0.70$ (hexanes/EtOAc, 2:1). ${ }^{1} \mathrm{H}$ NMR $\left(500 \mathrm{MHz}, \mathrm{CDCl}_{3}\right): \delta 1.10(\mathrm{~s}, 9 \mathrm{H}$, $\left.\mathrm{SiC}\left(\mathrm{CH}_{3}\right)_{3}\right), 1.36-1.42\left(\mathrm{~m}, 1 \mathrm{H}, 6^{\prime}-\mathrm{H}_{\mathrm{a}}\right), 1.58-1.65$ (m, 2H, 2'- $\left.\mathrm{H}_{\mathrm{a}}, 3^{\prime}-\mathrm{H}_{\mathrm{a}}\right), 1.76-1.81\left(\mathrm{~m}, 1 \mathrm{H}, 2^{\prime}-\right.$ $\mathrm{H}_{\mathrm{b}}$ ), 1.89-1.98 (m, 2H, 6'- $\left.\mathrm{H}_{\mathrm{b}}, 3^{\prime}-\mathrm{H}_{\mathrm{b}}\right), 2.29-2.34$ (m, 1H, 6a'-H), 2.45-2.52 (m, 1H, 3a'-H), 3.86-3.92 (m, 4H, $\left.\mathrm{OCH}_{2} \mathrm{CH}_{2} \mathrm{O}\right), 3.96-4.00\left(\mathrm{~m}, 2 \mathrm{H}, 4^{\prime}-\mathrm{H}, 5^{\prime}-\mathrm{H}\right), 7.36-7.40(\mathrm{~m}, 4 \mathrm{H}, o-\mathrm{H})$, 7.41-7.44 (m, 2H, $p$-H), 7.66-7.72 (m, 4H, $m-\mathrm{H})$ ppm; ${ }^{13} \mathrm{C}$ NMR (125 MHz, $\left.\mathrm{CDCl}_{3}\right): \delta 19.4$ ( $\left.\mathrm{SiC}\left(\mathrm{CH}_{3}\right)_{3}\right), 22.6$ (C-3'), $27.1\left(\mathrm{SiC}\left(\mathrm{CH}_{3}\right)_{3}\right), 30.4$ (C-6'), 35.1 (C-2'), 42.8 (C-3a'), 44.7 (C6a'), $64.1\left(\mathrm{OCH}_{2} \mathrm{CH}_{2} \mathrm{O}\right), 65.0\left(\mathrm{OCH}_{2} \mathrm{CH}_{2} \mathrm{O}\right), 77.4$ (C-4'/C-5'), 81.4 (C-4'/C-5'), 118.7 (C-1'), 127.7 (C-o), 127.8 (C-o), 129.8 (C-p), 129.9 (C-p), 133.7 (C-i), 134.5 (C-i), 135.8 (C-o), 135.9 (C-o) ppm; FT-IR (ATR): $\tilde{v}=2955$ (m), 2889 (m), 2857 (m), $1472(\mathrm{w}), 1427(\mathrm{w})$, 1362 (w), 1104 (m), 1041 (m), 942 (w), 906 (vs), 855 (m), 821 (m), 729 (vs), 701 (vs), 649 (m), $612(\mathrm{~m}) \mathrm{cm}^{-1}$; MS (ESI): $m / z=439.23[\mathrm{M}+\mathrm{H}]^{+}, 361.18[\mathrm{M}-\mathrm{Ph}]^{+}, 317.16,299.15$, 283.14, 239.11 [M-TBDPS $]^{+}$, 235.11, 183.10, 165.09, 139.07, 121.06, 105.04; HRMS (ESI): calcd. for $\mathrm{C}_{26} \mathrm{H}_{34} \mathrm{O}_{4} \mathrm{SiNa}^{+}[\mathrm{M}+\mathrm{Na}]^{+}$461.2119; found 461.2125.

\section{9. rac 3-But-3-enyl-2,3,3a,6a-tetrahydropentalene-1,4-dione (23a)}

To a suspension of $\mathrm{CuCN}(0.55 \mathrm{~g}, 6.16 \mathrm{mmol})$ in freshly distilled THF was added TMEDA $(0.66 \mathrm{~mL}, 0.75 \mathrm{~g}, 4.40 \mathrm{mmol})$ and the reaction mixture cooled to $-78^{\circ} \mathrm{C}$. A solution of 3-butenylmagnesiumbromide, freshly prepared from $\mathrm{Mg}(0.43 \mathrm{~g}, 17.6 \mathrm{mmol})$ and 4-bromo-1-butene $(0.49 \mathrm{~mL}, 0.65 \mathrm{~g}, 4.80 \mathrm{mmol})$, was slowly added dropwise and the reaction mixture stirred for $20 \mathrm{~min}$ at $-78{ }^{\circ} \mathrm{C}$. Then $\mathrm{TMSCl}(0.68 \mathrm{~mL}, 0.58 \mathrm{~g}, 5.28 \mathrm{mmol})$ was added followed 
by a cold solution of $22(0.59 \mathrm{~g}, 4.40 \mathrm{mmol})$ in THF $(5 \mathrm{~mL})$. After stirring for $30 \mathrm{~min}$, the reaction mixture was hydrolyzed with a mixture from a satd. $\mathrm{NH}_{4} \mathrm{Cl}$ solution/25\% ic $\mathrm{NH}_{3}$ solution $(10: 1,15 \mathrm{~mL})$. The layers were separated and the aqueous layer was extracted with $\mathrm{Et}_{2} \mathrm{O}(3 \times 10 \mathrm{~mL})$. A $1 \mathrm{~N} \mathrm{HCl}$ solution was added to the combined organic layers, and the mixture stirred for $30 \mathrm{~min}$ to hydrolyze the formed silyl enol ether. The layers were separated and the organic layer was dried $\left(\mathrm{MgSO}_{4}\right)$ and concentrated. The residue was purified by flash chromatography (hexanes/ EtOAc, 4:1) to give 23a (530 mg, $2.77 \mathrm{mmol}, 63 \%$ ) as a yellow oil. $R_{\mathrm{f}} 0.5$ (hexanes/EtOAc, 2:1). ${ }^{1} \mathrm{H}$ NMR $\left(500 \mathrm{MHz}, \mathrm{CDCl}_{3}\right): \delta 1.45-1.54\left(\mathrm{~m}, 1 \mathrm{H}, 7-\mathrm{H}_{\mathrm{a}}\right)$, 1.69-1.78 (m, 1H, 7- $\mathrm{H}_{\mathrm{b}}$ ), 2.05-2.20 (m, 3H, 2-H $\left.\mathrm{a}, 8-\mathrm{H}\right), 2.30-2.38$ (m, 1H, 3-H), 2.53 (ddt, $J$ $\left.=17.8,8.0,0.8 \mathrm{~Hz}, 1 \mathrm{H}, 2-\mathrm{H}_{\mathrm{b}}\right), 2.77(\mathrm{ddt}, J=6.4,3.6,0.8 \mathrm{~Hz}, 1 \mathrm{H}, 3 \mathrm{a}-\mathrm{H}), 3.59-3.63(\mathrm{~m}, 1 \mathrm{H}$, 6a-H), 4.95-5.05 (m, 2H, 10-H), 5.72-5.82 (m, 1H, 9-H), 6.20-6.23 (m, 1H, 5-H), 7.56-7.58

(m, 1H, 6-H) ppm; ${ }^{13} \mathrm{C}$ NMR (125 MHz, $\left.\mathrm{CDCl}_{3}\right)$ : $\delta 31.6$ (C-8), 35.6 (C-7), 35.8 (C-3), 43.2 (C-2), 52.6 (C-3a), 55.7 (C-6a), 115.6 (C-10), 134.9 (C-5), 137.6 (C-9), 159.5 (C-6), 210.0 (C-4), 212.2 (C-1) ppm; FT-IR (ATR): $\tilde{v}=3076$ (w), 2926 (m), 1740 (s), 1703 (vs), 1640 (m), 1580 (m), 1452 (w), 1409 (w), 1334 (w), 1173 (m), 1073 (w), 995 (w), 912 (m), 788 (m) $\mathrm{cm}^{-1}$; MS (EI, $\left.70 \mathrm{eV}\right): \mathrm{m} / z(\%)=190.1$ (2) $[\mathrm{M}]^{+}, 162.1$ (2), 148.1 (3), 135.0 (15) [M - $\left.\mathrm{C}_{4} \mathrm{H}_{7}\right]$, 108.1 (100) $\left[\mathrm{C}_{6} \mathrm{H}_{4} \mathrm{O}_{2}\right], 91.1$ (6), 81.1 (32), 67.1 (3), 55.0 (9); HRMS (EI): calcd. for $\mathrm{C}_{12} \mathrm{H}_{14} \mathrm{O}_{2}$ $[\mathrm{M}]^{+}$190.0994; found 190.0989 .

\subsection{0. rac 3'-But-3-enyl-2',3',3a',6a'-tetrahydro-4' $H$-spiro[1,3-dioxolane-2,1'-pentalen]- 4'-one (23b)}

To a solution of toluene $(5.00 \mathrm{~mL})$, ethylene glycol $(0.10 \mathrm{~mL}, 91 \mathrm{mg}, 1.47 \mathrm{mmol})$ and $p$ TsOH (13 mg, $0.07 \mathrm{mmol})$ was added 23a $(140 \mathrm{mg}, 0.74 \mathrm{mmol})$ and the reaction mixture heated at reflux for $7 \mathrm{~h}$. After cooling to room temperature, a satd. $\mathrm{NaHCO}_{3}$ solution $(5 \mathrm{~mL})$ was added and the layers were separated. The organic layer was washed with brine $(4 \mathrm{~mL})$ and then extracted with EtOAc $(10 \mathrm{~mL})$, dried $\left(\mathrm{MgSO}_{4}\right)$ and the solvent removed under reduced pressure. The residue was purified by preparative HPLC on a Kromasil column (250 $\times 20 \mathrm{~mm}, 5 \mu \mathrm{m}$ pore size; MZ Analysentechnik $\mathrm{GmbH})$ with hexanes/EtOAc (4:1) to give 23b (100 mg, $0.44 \mathrm{mmol}, 60 \%$ ) as a yellow oil. $R_{\mathrm{f}} 0.6$ (hexanes/EtOAc, $1: 1$ ). ${ }^{1} \mathrm{H}$ NMR (500 $\left.\mathrm{MHz}, \mathrm{CDCl}_{3}\right): \delta 1.54-1.65\left(\mathrm{~m}, 2 \mathrm{H}, 2-\mathrm{H}_{\mathrm{a}}, 7-\mathrm{H}_{\mathrm{a}}\right), 1.75-1.83\left(\mathrm{~m}, 1 \mathrm{H}, 7-\mathrm{H}_{\mathrm{b}}\right), 1.93(\mathrm{dd}, J=13.3$, $\left.7.4 \mathrm{~Hz}, 1 \mathrm{H}, 2-\mathrm{H}_{\mathrm{b}}\right), 2.00-2.07(\mathrm{~m}, 1 \mathrm{H}, 3-\mathrm{H}), 2.12$ (q, $\left.J=7.4 \mathrm{~Hz}, 2 \mathrm{H}, 8-\mathrm{H}\right), 2.51(\mathrm{dd}, J=6.5$, $4.3 \mathrm{~Hz}, 1 \mathrm{H}, 3 \mathrm{a}-\mathrm{H}), 3.36-3.40(\mathrm{~m}, 1 \mathrm{H}, 6 \mathrm{a}-\mathrm{H}), 3.86-4.05\left(\mathrm{~m}, 4 \mathrm{H}, \mathrm{OCH}_{2} \mathrm{CH}_{2} \mathrm{O}\right), 4.94-4.97(\mathrm{~m}$, $\left.1 \mathrm{H}, 10-\mathrm{H}_{\mathrm{a}}\right), 5.01-5.06\left(\mathrm{~m}, 1 \mathrm{H}, 10-\mathrm{H}_{\mathrm{b}}\right), 5.78-5.87(\mathrm{~m}, 1 \mathrm{H}, 9-\mathrm{H}), 6.14(\mathrm{ddd}, J=5.9,2.2,0.7$ $\mathrm{Hz}, 1 \mathrm{H}, 5-\mathrm{H}), 7.57$ (ddd, $J=5.6,2.9,0.7 \mathrm{~Hz}, 1 \mathrm{H}, 6-\mathrm{H}) \mathrm{ppm} ;{ }^{13} \mathrm{C} \mathrm{NMR}\left(125 \mathrm{MHz}, \mathrm{CDCl}_{3}\right): \delta$ 
32.1 (C-8), 35.0 (C-7), 38.5 (C-3), 40.7 (C-2), 54.0 (C-3a), 54.6 (C-6a), 64.7, 64.8 $\left(\mathrm{OCH}_{2} \mathrm{CH}_{2} \mathrm{O}\right.$ ), 114.9 (C-10), 116.1 (C-1), 134.2 (C-5), 138.5 (C-9), 162.7 (C-6), 211.7 (C-4) ppm; FT-IR (ATR): $\tilde{v}$ = 3074 (w), 2923 (m), 1702 (vs), 1640 (m), 1585 (m), 1437 (w), 1341 (m), 1175 (m), 1113 (m), 1066 (m), 1018 (m), 947 (m), 911 (m), 884 (w), 842 (w), 798 (w), 769 (w) $\mathrm{cm}^{-1}$; MS (EI, $\left.70 \mathrm{eV}\right): \mathrm{m} / z(\%)=234.1$ (33) $[\mathrm{M}]^{+}, 179.1$ (25) $\left[\mathrm{M}-\mathrm{C}_{4} \mathrm{H}_{7}\right], 153.1$ (100), 125.1 (6), 107.0 (31), 99.0 (8), 86.0 (19), 79.0 (10); HRMS (EI): calcd. for $\mathrm{C}_{14} \mathrm{H}_{18} \mathrm{O}_{3}$ $[\mathrm{M}]^{+}$234.1256; found: 234.1251 .

\subsection{Cytotoxicity assay}

3-(4,5-Dimethylthiazol-2-yl)-2,5-diphenyltetrazolium bromide (MTT) was used to measure growth and viability of cells which are capable of reducing it to a violet formazan product. 60 $\mu \mathrm{L}$ of serial dilutions of the test compounds were added to $120 \mu \mathrm{L}$ aliquots of a cell suspension $\left(50000 \mathrm{~mL}^{-1}\right)$ in 96-well microplates. Blank and solvent controls were incubated under identical conditions for $5 \mathrm{~d}$. MTT in phosphate buffered saline (PBS) $(20 \mu \mathrm{L})$ was added to a final concentration of $0.5 \mathrm{mg} \mathrm{mL}^{-1}$. After $2 \mathrm{~h}$, the precipitate of formazan crystals was centrifuged, and the supernatant discarded. The precipitate was washed with PBS (100 $\mu \mathrm{L})$ and dissolved in isopropanol containing $0.4 \%$ hydrochloric acid $(100 \mu \mathrm{L})$. The microplates were gently shaken for $20 \mathrm{~min}$ to ensure a complete dissolution of the formazan and finally measured at $595 \mathrm{~nm}$ using an ELISA plate reader. All experiments were carried out in two parallel experiments. Activity values were calculated as the mean with respect to the controls set to $100 \%$.

\subsection{Cell staining}

$\mathrm{PtK}_{2}$ cells (ATCC CCL-56) were grown in $750 \mu \mathrm{L}$ medium in 4-well plates (Nunc) on glass coverslips, and incubated with the test compound overnight. For F-actin staining cells were fixed with formalin $(3.7 \%)$ for $10 \mathrm{~min}$, permeabilized with $0.1 \%$ Triton X-100 for $5 \mathrm{~min}$, and then incubated with Alexa Fluor 488 phalloidin (1:100; Molecular Probes) for $1 \mathrm{~h}$. For ER and $\alpha$-tubulin staining cells were fixed with cold $\left(-20^{\circ} \mathrm{C}\right) \mathrm{MeOH} / \mathrm{ace}-$ tone (1:1) for 10 min and later incubated with a primary antibody against GRP-94 (1:1000; Affinity Bioreagents) and $\alpha$-tubulin (1:100; Sigma), respectively, and then with a secondary Alexa Fluor 488 goat anti-rat IgG antibody (1:200; Molecular Probes) and Alexa Fluor 488 goat anti-mouse IgG antibody (1:200; Molecular Probes), respectively, and mounted in ProLong Antifade Gold (Molecular Probes), which included DAPI to stain the nuclei. 


\subsection{Click chemistry}

$\mathrm{PtK}_{2}$ cells (ATCC CCL-56) were grown in $750 \mu \mathrm{L}$ medium in 4-well plates (Nunc) on glass coverslips, and incubated with 11a $\left(3 \mu \mathrm{g} \mathrm{mL} \mathrm{m}^{-1}\right)$ overnight. Cells were fixed with formalin $(3.7 \%)$ for $10 \mathrm{~min}$ and permeabilized with $0.1 \%$ Triton $\mathrm{X}-100$ for $5 \mathrm{~min}$. Cells were blocked with $3 \%$ FBS in PBS at $37^{\circ} \mathrm{C}$ for 5 min. The Click-iT cocktail was prepared as per the manufacturer's protocol just prior its usage and cells were incubated for $30 \mathrm{~min}$. For colocalization studies, further staining was carried out for F-actin using Alexa Fluor 488 phalloidin (Ph488, 1:100 with 10\% FBS, Molecular Probes), and mounted in ProLong Antifade Gold (Molecular Probes) without DAPI.

\subsection{Impedance measurement profiling}

The impedance of incubated cell cultures was monitored on a RT-CES system (xCelligence) from Acea Biosciences (Roche). The resulting impedance curves were used for a hierarchical cluster analysis of reference compounds together with compound of unknown mode of action. Co-clustering of the compound of unknown mode of action with reference compounds with known activity class label is used to predict the mode of action. The method was described previously. ${ }^{26}$

\subsection{Tubulin polymerization assay}

This assay was carried out according to manufacturer's protocol (Tubulin Polymerization Assay Kit, Catalog \#: BK0011P; Cytoskeleton). Tubulin master mix was prepared which included buffer, glycerol, GTP stock $(100 \mathrm{mM})$ and porcine tubulin $\left(10 \mathrm{mg} \mathrm{mL}^{-1}\right)$ according to the manufacturer's guidelines - all were provided in the kit. $5 \mu \mathrm{L}$ of the compounds were added to $50 \mu \mathrm{L}$ of tubulin mix in a 96-well plate which was immediately placed in a thermoregulated fluorimeter maintained at $37^{\circ} \mathrm{C}$. Fluorescence was measured for about an hour at $460 \mathrm{~nm}$ (excitation: $340 \mathrm{~nm})$.

\subsection{Actin polymerization assay}

This assay was carried out according to manufacturer's protocol (Actin Polymerization Biochem Kit, Catalog \#: BK003; Cytoskeleton). According to the manufacturer's guidelines buffer and actin were prepared. The actin stock was added to a 96-well plate and fluorescence was read at $410 \mathrm{~nm}$ (excitation: $360 \mathrm{~nm}$ ) for $3 \mathrm{~min}$ for a baseline reading. After $3 \mathrm{~min}$ test 
compounds $(20 \mu \mathrm{L})$ were added and read for another $20 \mathrm{~min}$. This was followed by addition of $10 \mathrm{X}$ actin polymerization buffer and readings were taken for an hour.

\section{Acknowledgements}

Generous financial support by the Deutsche Forschungsgemeinschaft, the Ministerium für Wissenschaft, Forschung und Kunst des Landes Baden-Württemberg (Landesgraduierten fellowship for N.P.), the DAAD (fellowship for N.P.) and the Fonds der Chemischen Industrie and is gratefully acknowledged.

\section{Supplementary data}

Supplementary data associated with this article can be found, in the online version, at http://正.

\section{References and notes}

1. (a) Kanazawa, S.; Fusetani, N.; Matsunaga, S. Tetrahedron Lett. 1993, 34, 1065-1068;

(b) Krol, W. J.; Mao, S. S.; Steele, D. L.; Townsend, C. A. J. Org. Chem. 1991, 56, 728 731.

2. (a) Cramer, N.; Laschat, S.; Baro, A.; Schwalbe, H.; Richter, C. Angew. Chem. 2005, 117, 831-833; Angew. Chem. Int. Ed. 2005, 44, 820-822; (b) Cramer, N.; Buchweitz, M.; Laschat, S.; Frey, W.; Baro, A.; Mathieu, D.; Richter, C.; Schwalbe, H. Chem. Eur. J. 2006, 12, 2488-2503; (c) Hart, A. C.; Phillips, A. J. J. Am. Chem. Soc. 2006, 128, 10941095.

3. (a) Shigemori, H.; Bae, M.-A.; Yazawa, K.; Sasaki, T.; Kobayashi, J. J. Org. Chem. 1992, 57, 4317-4320; (b) Yazawa, K.; Yamada, K.; Pei, A.; Kobayashi, J.; Shigemori, H. Jpn. Kohai Tokkyo Koho (1993) JP 05230065A.

4. (a) Capon, R. J.; Skene, C.; Lacey, E.; Gill, J. H.; Wadsworth, D.; Friedel, T. J. Nat. Prod. 1999, 62, 1256-1259; (b) Capon, R. J. Eur. J. Org. Chem. 2001, 633-645.

5. Phillips, A. J.; Hart, A. C.; Henderson, J. A. Tetrahedron Lett. 2006, 47, 3743-3745.

6. (a) Bae, M.-A.; Yamada, K.; Ijuin, Y.; Tsuji, T.; Yazawa, K.; Tomono, Y.; Uemura, D. Heterocycl. Commun. 1996, 2, 315-318; (b) Yamada, K.; Kuramoto, M.; Uemura, D. Recent Res. Develop. Pure Appl. Chem. 1999, 3, 245-254.

7. Henderson, J. A.; Phillips, A. J. Angew. Chem. 2008, 120, 8627-8629; Angew. Chem. Int. Ed. 2008, 47, 8499-8501. 
8. (a) Takeda, R.; Naoki, H.; Iwashita, T.; Hirose, Y. Tetrahedron Lett. 1981, 22, 53075310; (b) Takeda, R.; Naoki, H.; Iwashita, T.; Mizukawa, K.; Hirose, Y.; Isida, T.; Inoue, M. Bull. Chem. Soc. Jpn. 1983, 56, 1125-1132; (c) Toyota, M.; Koyama, H.; Hashimoto, T.; Asakawa, Y. Chem. Pharm. Bull. 1995, 43, 714-716; (d) Wu, C.-L.; Wang, C.-J.; Yin, M.-H. J. Chin. Chem. Soc. 2001, 48, 241-247; (e) Ludwiczuk, A.; Nagashima, F.; Gradstein, R. S.; Asakawa, Y. Nat. Prod. Commun. 2008, 3, 133-140.

9. (a) Huguet, J.; Karpf, M.; Dreiding, A. S. Tetrahedron Lett. 1983, 24, 4177-4180; (b) Bieri, J. H.; Huguet, J.; Karpf, M.; Prewo, R. Acta Cryst. 1987, C43, 1964-1966; (c) Solaja, B.; Huguet, J.; Karpf, M.; Dreiding, A. S. Tetrahedron 1987, 43, 4875-4886; (d) Hashimoto, H.; Abe, Y.; Mayuzumi, Y.; Karikomi, M.; Seki, K.; Haga, K.; Uyehara, T. Tetrahedron Lett. 2002, 43, 265-267; (e) Singh, V.; Chandra, G.; Mobin, S. M. Synlett 2008, 3111-3114.

10. (a) Bae, M.-A.; Yamada, K.; Uemura, D.; Seu, J.-H.; Kim, Y.-H. J. Microbiol. Biotechnol. 1998, 8, 455-460; (b) Bae, M.-A.; Kang, H. S.; Rue, S. W.; Seu, J. H.; Kim, Y. H. Biochem. Biophys. Res. Commun. 1998, 246, 276-281.

11. Barnickel, B.; Bayliffe, F.; Diestel, R.; Kempf, K.; Laschat, S.; Pachali, S.; Sasse, F.; Schlenk, A.; Schobert, R. Chem. Biodiv. 2010, 7, 2830-2845.

12. Cramer, N.; Helbig, S.; Baro, A.; Laschat, S.; Diestel, R.; Sasse, F.; Mathieu, D.; Richter, C.; Kummerlöwe, G.; Luy, B.; Schwalbe, H. ChemBioChem 2008, 9, 2474-2486.

13. (a) Ochiai, H.; Ohtani, T.; Ishida, A.; Kishikawa, K.; Yamamoto, S.; Takeda, H.; Obata, T.; Nakai, H.; Toda, M. Eur. J. Med. Chem. 2004, 39, 555-571; (b) Ochiai, H.; Ohtani, T.; Ishida, A.; Kishikawa, K.; Obata, T.; Nakai, H.; Toda, M. Bioorg. Med. Chem. Lett. 2004, 14, 1323-1327.

14. (a) Klar, U.; Pletsch, A. Bioorg. Med. Chem. Lett. 1993, 3, 199-204; (b) Hayashi, M.; Arai, Y.; Wakatsuka, H.; Kawamura, M.; Konishi, Y.; Tsuda, T.; Matsumoto, K. J. Med. Chem. 1980, 23, 525-535.

15. Fairlamb, I. J. S.; Dickinson, J. M.; O’Connor, R.; Higson, S.; Grieveson, L.; Marin, V. Bioorg. Med. Chem. 2002, 10, 2641-2656.

16. Bertz, S. H.; Cook, J. M.; Gawish, A.; Weiss, U. Org. Synth. 1986, 64, 27-38; Coll. Vol. $7,1990,50-59$.

17. Lutz, V.; Baro, A.; Fischer, P.; Laschat, S. Eur. J. Org. Chem. 2010, 1149-1157.

18. (a) Vaulont, I.; Gais, H.-J.; Reuter, N.; Schmitz, E.; Ossenkamp, R. K. L. Eur. J. Org. Chem. 1998, 805-826; (b) Anderl, T.; Emo, M.; Laschat, S.; Baro, A.; Frey, W. Synthesis 2008, 1619-1627. 
19. Lutz, V.; Park, N.; Rothe, C.; Krüger, C.; Baro, A.; Laschat, S. Eur. J. Org. Chem. 2013, 761-771.

20. (a) Tu, Y.; Wang, Z.-X.; Shi, Y. J. Am. Chem. Soc. 1996, 118, 9806-9807; (b) Mio, S.; Kumagawa, Y.; Sugai, S. Tetrahedron 1991, 47, 2133-2144.

21. Mihovilovic, M. D.; Müller, B.; Kayser, M. M.; Stewart, J. D.; Stanetty, P. Synlett 2002, 703-706.

22. Mosman, T. J. Immunol. Methods 1983, 65, 55-63.

23. Karimi, B.; Zareyee, D. Tetrahedron Lett. 2005, 46, 4661-4665.

24. Garcia Sancho, A.; Wang, X.; Sui, B.; Curran, D. P. Adv. Synth. Catal. 2009, 351, 10351040.

25. Chang, S.-Y.; Jiaang, W.-T.; Cherng, C.-D.; Tang, K.-H.; Huang, C.-H.; Tsai, Y.-M. J. Org. Chem. 1997, 62, 9089-9098.

26. Ushakov, D. B.; Raja, A.; Franke, R.; Sasse, F.; Maier, M. E. Synlett 2012, 23, 13581360.

27. Dabydeen, D. A.; Florence, G. J.; Paterson, I.; Hamel, E. Cancer Chemother. Pharmacol. 2004, 53, 397-403.

28. (a) Kolb, H. C.; Finn, M. G.; Sharpless, K. B. Angew. Chem. 2001, 113, 2056-2075; Angew. Chem. Int. Ed. 2001, 40, 2004-2021; (b) Wang, M.; Yuan, Y.; Liang, G. Current Molecular Imaging 2012, 1, 87-95; (c) Kolb, H. C.; Sharpless, K. B. Drug Discovery Today 2003, 8, 1128-1137.

29. (a) Tornøe, C. W.; Christensen, C.; Meldal, M. J. Org. Chem. 2002, 67, 3057-3064; (b) Rostovtsev, V. V.; Green, L. G.; Fokin, V. V.; Sharpless, K. B. Angew. Chem. 2002, 114, 2708-2711; Angew. Chem. Int. Ed. 2002, 41, 2596-2599; (c) Meldal, M.; Tornøe, C. W. Chem. Rev. 2008, 108, 2952-3015; (d) Hein, J. E.; Fokin, V. V. Chem. Soc. Rev. 2010, 39, 1302-1315; (e) Liang, L.; Astruc, D. Coord. Chem. Rev. 2011, 255, 2933-2945. 